\title{
Stress-Induced Recruitment of Bone Marrow-Derived Monocytes to the Brain Promotes Anxiety-Like Behavior
}

\author{
Eric S. Wohleb, ${ }^{1,2}$ Nicole D. Powell, ${ }^{1}$ Jonathan P. Godbout, ${ }^{2,3,4}$ and John F. Sheridan ${ }^{1,3,4}$ \\ ${ }^{1}$ Division of Oral Biology, ${ }^{2}$ Department of Neuroscience, ${ }^{3}$ Institute for Behavioral Medicine Research, ${ }^{4}$ Center for Brain and Spinal Cord Repair, The Ohio \\ State University, Columbus, Ohio 43210
}

\begin{abstract}
Social stress is associated with altered immunity and higher incidence of anxiety-related disorders. Repeated social defeat (RSD) is a murine stressor that primes peripheral myeloid cells, activates microglia, and induces anxiety-like behavior. Here we show that RSDinduced anxiety-like behavior corresponded with an exposure-dependent increase in circulating monocytes $\left(\mathrm{CD} 11 \mathrm{~b}^{+} / \mathrm{SSC}^{\mathrm{lo}} / \mathrm{Ly} 6 \mathrm{C}^{\mathrm{hi}}\right)$ and

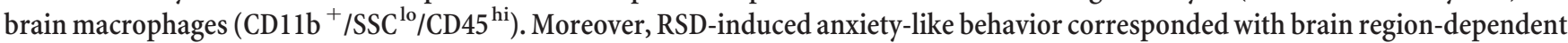
cytokine and chemokine responses involved with myeloid cell recruitment. Next, LysM-GFP ${ }^{+}$and $\mathrm{GFP}^{+}$bone marrow (BM)-chimeric mice were used to determine the neuroanatomical distribution of peripheral myeloid cells recruited to the brain during RSD. LysM-GFP ${ }^{+}$ mice showed that RSD increased recruitment of $\mathrm{GFP}^{+}$macrophages to the brain and increased their presence within the perivascular space (PVS). In addition, RSD promoted recruitment of $\mathrm{GFP}^{+}$macrophages into the PVS and parenchyma of the prefrontal cortex, amygdala, and hippocampus of $\mathrm{GFP}^{+} \mathrm{BM}$-chimeric mice. Furthermore, mice deficient in chemokine receptors associated with monocyte trafficking [chemokine receptor-2 knockout $\left(\mathrm{CCR} 2{ }^{\mathrm{KO}}\right)$ or fractalkine receptor knockout $\left(\mathrm{CX}_{3} \mathrm{CR} 1^{\mathrm{KO}}\right)$ ] failed to recruit macrophages to the brain and did not develop anxiety-like behavior following RSD. Last, RSD-induced macrophage trafficking was prevented in BMchimeric mice generated with $\mathrm{CCR} 2{ }^{\mathrm{KO}}$ or $\mathrm{CX}_{3} \mathrm{CR} 1{ }^{\mathrm{KO}}$ donor cells. These findings indicate that monocyte recruitment to the brain in response to social stress represents a novel cellular mechanism that contributes to the development of anxiety.
\end{abstract}

\section{Introduction}

Psychosocial stressors promote inflammation and immune dysfunction (Glaser and Kiecolt-Glaser, 2005), which are implicated in development of mood disorders (Haroon et al., 2012). We propose that stress-associated release and redistribution of primed myeloid cells is an important link between immune dysfunction and development of mood disorders. Under stressful stimuli, peripheral myeloid cells can produce proinflammatory cytokines (Brydon et al., 2005) and readily traffic to peripheral tissues (Dhabhar et al., 2012). Repeated social defeat (RSD) is a murine stressor that generates "primed" peripheral myeloid $\left(\mathrm{CD} 11 \mathrm{~b}^{+}\right)$cells and causes anxiety-like behavior (Kinsey et al., 2007; Krishnan et al., 2007). For example, peripheral myeloid cells are termed "primed" after RSD because they are glucocorticoid-insensitive (Stark et al., 2001), hyperinflammatory when activated (Bailey et al., 2009), and readily traffic to several organs, including the brain. Myeloid cell trafficking in the

Received April 19, 2013; revised June 27, 2013; accepted July 18, 2013.

Author contributions: E.S.W., J.P.G., and J.F.S. designed research; E.S.W. and N.D.P. performed research; E.S.W. and J.F.S. analyzed data; E.S.W., J.P.G., and J.F.S. wrote the paper.

This research was supported by National Institute of Mental Health (NIMH) Grant R01-MH093473 to J.F.S. and National Institute on Aging Grant R01-AG033028 to J.P.G. E.S.W. was supported by NIMH Predoctoral Fellowship F31-MH09547301. We thank Dr. Tim Eubank for providing CCR2 ${ }^{\mathrm{K} 0}$ mice and Dr. Dorian McGavern for providing LysM-GFP breeders. We also thank Daniel Shea, Yan Huang, and Annie Pacenta for their technical assistance.

The authors declare no competing financial interests.

Correspondence should be addressed to either of the following: John F. Sheridan, 223 IBMR Building, 460 Medical Center Drive, Columbus, OH 43210, E-mail: John.Sheridan@osumc.edu; or Jonathan Godbout, 259 IBMR Building, 460 Medical Center Drive, Columbus, $0 \mathrm{H} 43210$, E-mail: Jonathan.Godbout@osumc.edu.

DOI:10.1523/JNEUROSCI.1671-13.2013

Copyright $\odot 2013$ the authors $\quad 0270-6474 / 13 / 3313820-14 \$ 15.00 / 0$ brain after RSD is important because it coincides with activation of resident microglia and increases proinflammatory cytokine production (Wohleb et al., 2011). Thus, RSD increases the inflammatory potential of peripheral and central myeloid cells, but their contribution to stress-induced anxiety is unclear.

Our previous studies have established that RSD increases myelopoiesis, promotes macrophage trafficking to the brain, and induces anxiety-like behavior (Engler et al., 2004; Wohleb et al., 2011). Trafficking of circulating monocytes to inflammatory sites is dependent on phenotype and expression of either chemokine receptor-2 (CCR2) or fractalkine receptor $\left(\mathrm{CX}_{3} \mathrm{CR} 1\right)$ in mice (Geissmann et al., 2003; Auffray et al., 2007). In the context of RSD, myeloid cell trafficking in the brain may be mediated by similar mechanisms in the absence of neuropathology. Moreover, redistribution of myeloid cells in the brain is important because these cells mediate neuroimmune signaling and behavioral responses following immune challenge or stress (Serrats et al., 2010; Wohleb et al., 2012). Thus, stress-induced recruitment of "primed" peripheral macrophages to the brain likely influences the neuroinflammatory profile and alters behavioral responses. In support of this notion, $\beta$-adrenergic receptor antagonism has been shown to block RSD-induced trafficking of myeloid cells, microglial activation, and anxiety-like behavior (Wohleb et al., 2011; Hanke et al., 2012). In addition, recent studies indicate that secondary inflammatory mediators underlie neuronal adaptations that promote stress-associated mood disorders (Christoffel et al., 2011; Tanaka et al., 2012). Therefore, the objectives of this study were to (1) determine the temporal relationship between macrophage recruitment in the brain and 
anxiety-like behavior and (2) examine the distribution and extent to which macrophage recruitment in the brain promoted stressinduced anxiety-like behavior.

Here we show that RSD increased the release of monocytes into circulation that trafficked to the brain perivascular space (PVS) and parenchyma. In $\mathrm{GFP}^{+}$bone marrow (BM)-chimera mice, stress-induced macrophage recruitment was evident in specific brain regions implicated in anxiety responses. Moreover, recruitment of macrophages to the brain was integral for stressinduced anxiety-like behavior and required expression of two key chemokine receptors, CCR2 and $\mathrm{CX}_{3} \mathrm{CR} 1$. Last, our data indicate that peripheral myeloid cells are actively recruited to the brain with stress by resident microglia. These findings provide insight into how stress-associated recruitment of myeloid cells to the brain directly influences behavior.

\section{Materials and Methods}

Mice. Male C57BL/6 (6-10 weeks old) and CD-1 (12 months old) mice were purchased from Charles River Breeding Laboratories and allowed to acclimate to their surroundings for 7-10 d before initiation of any experimental procedures. C57BL/6-Tg ${ }^{(\mathrm{CAG}-\mathrm{EGFP})} 131 /$ leysopJ (\#006567) and transgenic CCR2 mice (CCR2 ${ }^{\mathrm{HET}(+/ \mathrm{RFP})}$ and CCR2 $\left.{ }^{\mathrm{KO}(\mathrm{RFP} / \mathrm{RFP})}\right)$ were purchased from Jackson Laboratories. Breeder pairs for LysM$\mathrm{GFP}^{(+/ \mathrm{GFP})}$ mice were provided by Dorian MacGavern [National Institutes of Health (NIH)]. LysM-GFP ${ }^{(+/ G F P)}$, chemokine receptor-2 knockout (CCR2 ${ }^{\mathrm{KO}}$ ) mice, and transgenic $\mathrm{CX}_{3} \mathrm{CR} 1$ mice $\left(\mathrm{CX}_{3} \mathrm{CR} 1^{\mathrm{HET}(+/ \mathrm{GFP})}\right.$ and $\left.\mathrm{CX}_{3} \mathrm{CR} 1^{\mathrm{KO}(\mathrm{GFP} / \mathrm{GFP})}\right)$ on the $\mathrm{C} 57 \mathrm{BL} / 6$ background were obtained from colonies at the Ohio State University. C57BL/6 mice were housed in cohorts of three and CD-1 mice were singly housed. All mice were housed in $11.5 \times 7.5 \times 6$ inch polypropylene cages. Rooms were maintained at $21^{\circ} \mathrm{C}$ under a $12 \mathrm{~h} \mathrm{light/dark}$ cycle with ad libitum access to water and rodent chow. All procedures were in accordance with the NIH Guidelines for the Care and Use of Laboratory Animals and were approved by the Ohio State University Institutional Laboratory Animal Care and Use Committee.

$R S D$. Mice were subjected to RSD as previously described (Wohleb et al., 2011, 2012). In brief, an aggressive intruder male CD-1 mouse (retired breeder) was introduced into cages of established male cohorts (three per cage) of C57BL/6 mice for 6 consecutive nights between 5:00 and 7:00 P.M. (2 h). During each cycle, submissive behavior including upright posture, fleeing, and crouching were observed to ensure that the resident mice showed subordinate behavior. If the intruder did not initiate a defeat within 5-10 min or was defeated by any of the resident mice, then a new intruder was introduced. At the end of the $2 \mathrm{~h}$ period, the intruder was removed and the residents were left undisturbed until the following day when the paradigm was repeated. Different intruders were used on consecutive nights. The health status of the mice was carefully examined throughout the paradigm. Mice that were injured or moribund were removed from the study. Consistent with previous studies using RSD, $<5 \%$ of mice met the early removal criteria (Wohleb et al., 2011, 2012). Control mice were left undisturbed in their home cages until killed.

Anxiety-like behavior. Anxiety-like behavior was determined using open-field activity and light-dark preference tests as previously described (Kinsey et al., 2007; Bailey et al., 2009; Wohleb et al., 2011, 2012; Hanke et al., 2012). For the open-field test, mice were placed in the corner of the test apparatus $(40 \times 40 \times 25 \mathrm{~cm}$ Plexiglas box $)$ and activity was recorded for $5 \mathrm{~min}$. Mice with anxiety-like behavior enter the center of the open-field slower and spend less time in the open field. For lightdark preference, the Plexiglas test apparatus $(40 \times 40 \times 25 \mathrm{~cm})$ was divided into equal zones (i.e., light or dark zones) with a doorway connecting the two sides. The dark zone was enclosed and had significantly less light ( $<3$ lux). To initiate testing, mice were placed into the light side and activity was recorded for $5 \mathrm{~min}$. Anxious mice entered the dark zone faster and spent more time in the dark zone. Both tests were recorded and analyzed using an automated system (VersaMax, AccuScan Instruments).
$\mathrm{GFP}^{+}$BM-chimera. To establish chimerism, recipient BM C57BL/6 male mice (6 weeks old) were injected intraperitoneally once daily for 2 consecutive days with busulfan in a 1:1 solution of DMSO and deionized $\mathrm{H}_{2} \mathrm{O}(30 \mathrm{mg} / \mathrm{kg} / 100 \mu \mathrm{l})$. This dose of busulfan resulted in partial BM ablation and limited morbidity. Donor BM-derived cells were isolated from the femur and passed through a $70 \mu \mathrm{m}$ cell strainer. Total number of cells was determined with a BD Coulter Particle Count and Size Analyzer (Beckman Coulter). Donor BM-derived cells were obtained from C57BL/6-Tg (CAG-EGFP), CCR2 $2^{\mathrm{HET}(+/ \mathrm{RFP})}, \quad \mathrm{CCR} 2^{\mathrm{KO}(\mathrm{RFP} / \mathrm{RFP})}$, $\mathrm{CX}_{3} \mathrm{CR} 1^{\mathrm{HET}(+/ \mathrm{GFP})}$, or $\mathrm{CX}_{3} \mathrm{CR} 1^{\mathrm{KO}(\mathrm{GFP} / \mathrm{GFP})}$ mice. BM-derived cells $(1 \times$ $10^{6}$ ) were transferred to recipient mice by tail vein injection $(100 \mu \mathrm{l}) 48 \mathrm{~h}$ after the second dose of busulfan. Mice were left undisturbed for 4 weeks to allow engraftment. Engraftment was verified by determining the percentage of $\mathrm{GFP}^{+}$cells in the BM and the blood. Mice that had $<30 \% \mathrm{BM}$ engraftment were excluded from the study.

Isolation of brain $\mathrm{CD}_{11 b^{+}}$cells. $\mathrm{CD} 11 \mathrm{~b}^{+}$cells were isolated from whole-brain homogenates as described previously (Wohleb et al., 2011, 2012). In brief, brains were passed through a $70 \mu \mathrm{m}$ cell strainer. Homogenates were centrifuged at $600 \times g$ for $6 \mathrm{~min}$. Supernatants were removed and cell pellets were resuspended in $70 \%$ isotonic Percoll (GEHealthcare). A discontinuous Percoll density gradient was layered as follows: 50, 35, and 0\% isotonic Percoll. The gradient was centrifuged for $20 \mathrm{~min}$ at $2000 \times g$ and cells were collected from the interphase between the 70 and 50\% Percoll layers. These cells were referred to as enriched brain $\mathrm{CD} 11 \mathrm{~b}^{+}$cells based on previous studies demonstrating that viable cells isolated by Percoll density gradient yields $>90 \% \mathrm{CD} 1 \mathrm{~b}^{+}$cells (Wohleb et al., 2011, 2012).

Isolation of blood leukocytes. Whole blood was collected with EDTAlined syringes by cardiac puncture immediately following $\mathrm{CO}_{2}$ asphyxiation. Red blood cells were lysed, samples were washed, and total number of leukocytes was determined with a BD Coulter Particle Count and Size Analyzer (Beckman Coulter).

Flow cytometry. Staining of cell surface antigens was performed as previously described (Wohleb et al., 2011, 2012). In brief, Fc receptors were blocked with anti-CD16/CD32 antibody (eBioscience). Cells were washed and then incubated with the appropriate antibodies (CD45, CD11b, Gr-1, eBioscience; Ly6C, BD Biosciences) for $1 \mathrm{~h}$ at $4^{\circ} \mathrm{C}$. Cells were washed and then resuspended in FACS buffer for analysis. Nonspecific binding was assessed using isotype-matched antibodies. Antigen expression was determined using a Becton-Dickinson FACSCalibur four-color cytometer (BD Biosciences). Data were analyzed using FlowJo software (Tree Star) and gating for each antibody was determined based on isotype stained controls.

Immunofluorescence. Brains were collected from mice after transcardial perfusion with sterile PBS, pH 7.4 (with EDTA), and 4\% formaldehyde. Brains were postfixed in $4 \%$ formaldehyde for $24 \mathrm{~h}$ and incubated in $20 \%$ sucrose for an additional $24 \mathrm{~h}$ at $4^{\circ} \mathrm{C}$. Fixed brains were frozen with isopentane $\left(-78^{\circ} \mathrm{C}\right)$ and sectioned $(20 \mu \mathrm{m})$ using a Microm HM550 cryostat. Brain regions were identified by reference markers in accordance with the stereotaxic mouse brain atlas (Paxinos and Franklin, 2008). To label for Iba-1 (ionized calcium binding adapter molecule-1), sections were mounted on slides or placed free-floating in cryoprotectant until staining. Next, sections were washed in PBS with $1 \%$ BSA, blocked with $2 \%$ normal goat serum, and incubated with a rabbit anti-mouse Iba-1 antibody (Wako Chemicals). To label for Ly6C, sections were washed in PBS with $1 \%$ BSA, blocked with 5\% normal goat serum, and incubated with a rat anti-mouse Ly6C antibody (Abcam). Next, sections were washed in PBS with 1\% BSA and incubated with a fluorochromeconjugated secondary antibody (Alexa Fluor 594: Iba-1; DyLight 350: Ly6C). Sections were mounted on slides and coverslipped with Fluoromount (Beckman Coulter) and stored at $-20^{\circ} \mathrm{C}$. Fluorescent sections were visualized using an epi-fluorescent Leica DM5000B microscope. Images were captured using a Leica DFC300 FX camera and imaging software.

Evans blue dye analysis. Male C57BL/6 mice were subjected to six cycles of social defeat (RSD) or left undisturbed as controls. Mice were retroorbitally injected with Evans blue dye $1 \mathrm{~h}$ before the final cycle of RSD. In a related study, busulfan was intraperitoneally injected for 2 consecutive days $(30 \mathrm{mg} / \mathrm{kg} / 100 \mu \mathrm{l})$. Two days after busulfan treatment (same time 
A

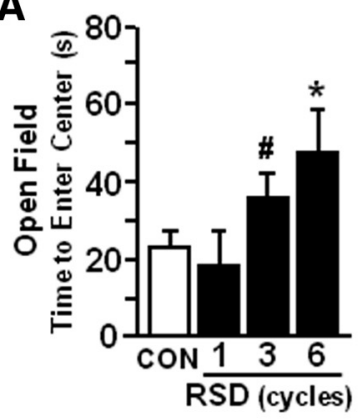

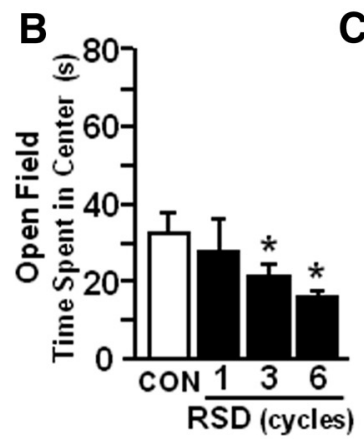
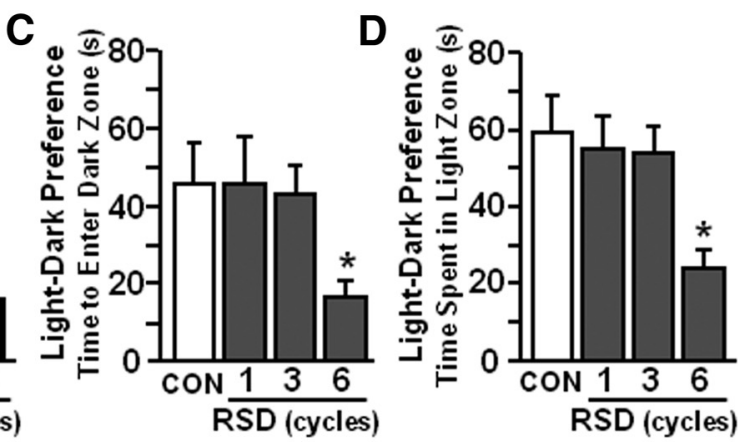

$\mathbf{E}$

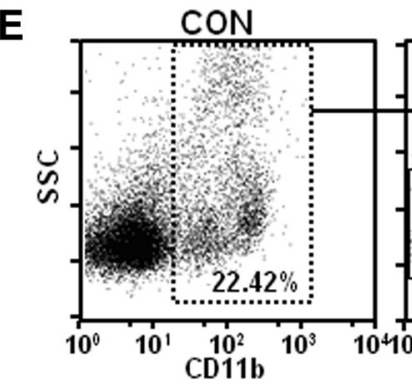

$\mathbf{F}$

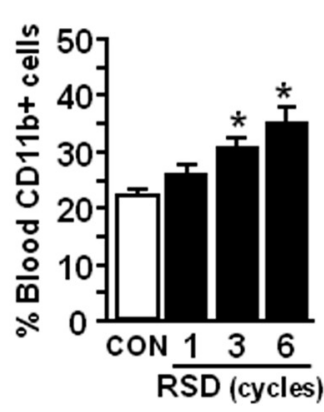

G
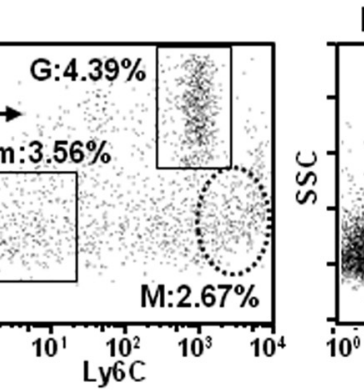

RSD (6 cycles)

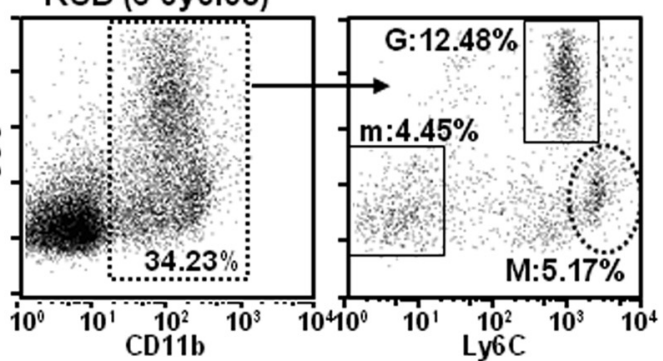

H
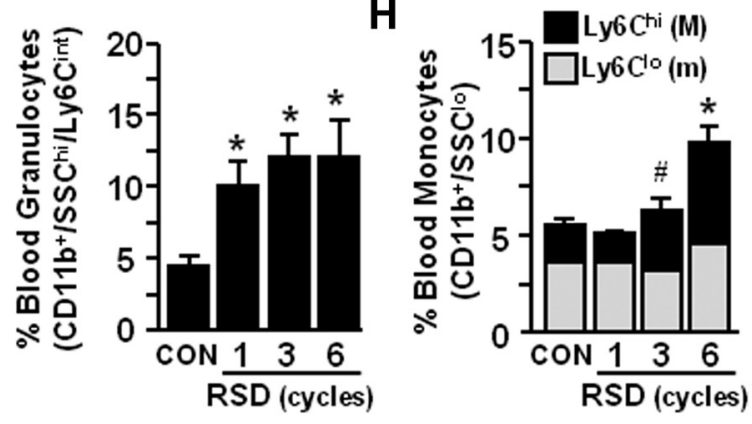

I
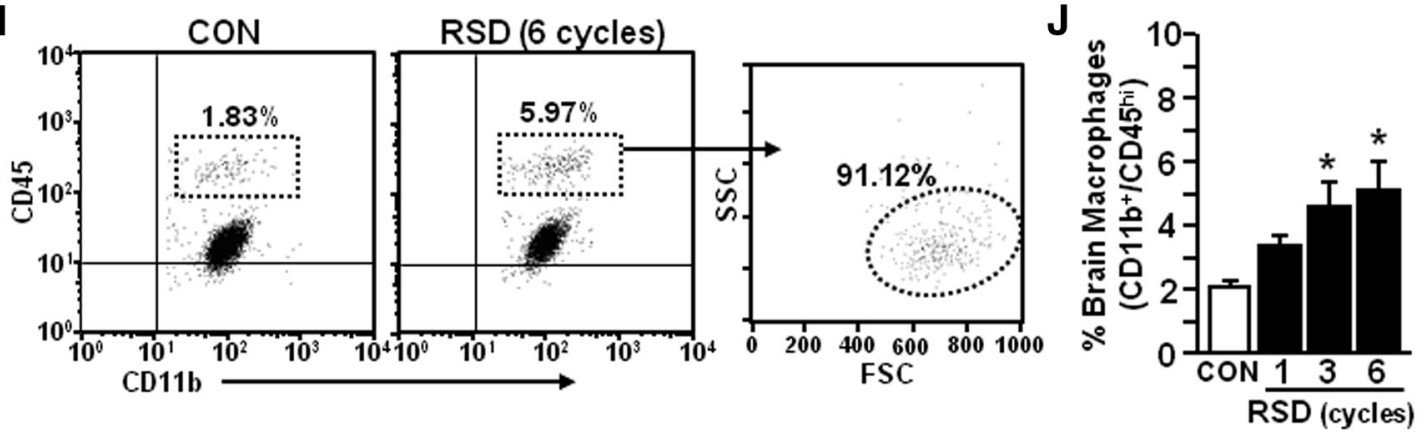

Figure 1. RSD-induced anxiety-like behavior was paralleled by an increased percentage of circulating monocytes (CD11b $\left.{ }^{+} / \mathrm{SSC}^{\mathrm{lo}} / \mathrm{Ly} 6 \mathrm{C}^{\text {hi }}\right)$ and macrophages (CD11b $\left.{ }^{+} / \mathrm{CD} 45^{\mathrm{hi}}\right)$ in the brain. Male C57BL/6 mice were subjected to one, three, or six cycles of social defeat (RSD) or left undisturbed as controls (CON). Anxiety-like behavior was determined $14 \mathrm{~h}$ after the final cycle of RSD ( $n=6-9$, 3 independent experiments). $\boldsymbol{A}, \boldsymbol{B}$, Time to enter the center of the open field $(\boldsymbol{A})$ and total time spent in the open field ( $\boldsymbol{B})$. $\boldsymbol{C}$, Time to enter the dark zone. $\boldsymbol{D}$, Total time spent in the light zone. Following behavioral testing, blood and enriched brain CD11b ${ }^{+}$cells were collected ( $n=6-9,3$ independent experiments). $\boldsymbol{E}$, Representative flow bivariate dot plots of SSC/CD11b and SSC/Ly6C labeling

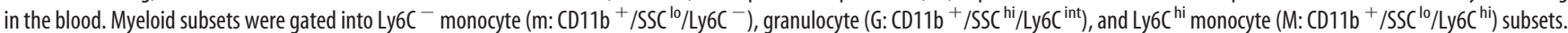
$\boldsymbol{F}-\boldsymbol{H}$, The percentage of blood myeloid cells $\left(\boldsymbol{F}, \mathrm{CD}_{11 \mathrm{~b}}{ }^{+}\right)$, granulocytes $(\boldsymbol{G}, \mathrm{G})$, and monocytes ( $\boldsymbol{H}, \mathrm{m}$ : Ly6C ${ }^{-}$or M: Ly6Chi). $\boldsymbol{I}$, Representative flow bivariate dot plots of CD11b/CD45 labeling in Percoll-isolated microglia/macrophages and side scatter/forward scatter (SSC/FSC) properties are shown in RSD mice. J, The percentage of brain macrophages (CD11b ${ }^{+} / C D 455^{\text {hi}}$ ) are shown. Bars represent the mean \pm SEM. Means with asterisk are significantly different from CON $(p<0.05)$ and means with number sign (\#) tended to be different from CON $(p<0.06-0.10)$.

point for BM cell transfer) mice were retro-orbitally injected with Evans blue dye. Mice were perfused and brains were collected for histology. Whole-brain images were taken and then brains were frozen and sectioned $(25 \mu \mathrm{m})$. Evans blue dye labeling was visualized in the brain on a fluorescent microscope with an A594 filter (red).

Classification of $\mathrm{GFP}^{+}$cell phenotype. $\mathrm{GFP}^{+}$cells in the brain were quantified and classified as previously described (Vallières and Sawchenko, 2003). In brief, $\mathrm{GFP}^{+}$cells that had a rod, elongated, or round/ amoeboid morphology were classified as rod/circular. Only GFP ${ }^{+}$cells that had distinct processes were classified as ramified (stellate). Because others report that rod/circular GFP ${ }^{+}$cells colocalized with blood vessels (Vallières and Sawchenko, 2003), these $\mathrm{GFP}^{+}$cells were designated as perivascular. Moreover, ramified (stellate) $\mathrm{GFP}^{+}$cells were determined to be parenchymal because they colocalized with Iba- 1 staining, but did not colocalize with vasculature (Ly6C).

RNA isolation and real-time PCR. RNA was isolated from homogenized brain regions using tri-reagent/isopropanol precipitation, RNA was reverse transcribed to cDNA using an RT-RETROscript kit (Am- 
bion) and RNA concentration was determined by spectrophotometry (Eppendorf). Quantitative PCR was performed using the Applied Biosystems Assay-on-Demand Gene Expression protocol as previously described (Wohleb et al., 2011, 2012). In brief, experimental cDNA was amplified by real-time PCR where a target cDNA (e.g., IL-1 $\beta$, CCL2, $\left.\mathrm{CX}_{3} \mathrm{CL} 1\right)$ and a reference cDNA [glyceraldehyde-3-phosphate dehydrogenase (GAPDH)] were amplified simultaneously using an oligonucleotide probe with a $5^{\prime}$ fluorescent reporter dye (6-FAM) and a $3^{\prime}$ quencher dye (nonfluorescent quencher). Fluorescence was determined on an ABI PRISM 7300-sequence detection system (Applied Biosystems). Data were analyzed using the comparative threshold cycle method and results are expressed as fold difference from GAPDH.

Statistical analysis. To test for normal distribution, data were subjected to Shapiro-Wilk test using Statistical Analysis Systems (SAS) statistical software (SAS). Observations $>3$ interquartile ranges from the first and third quartile were considered outliers and were excluded in the subsequent analysis. To determine significant main effects and interactions between main factors, data were analyzed using one-way (stress), or two-way (stress $\times$ genotype) ANOVA using the General Linear Model procedures of SAS. When there was a main effect of experimental treatment, differences between group means were evaluated by an $F$-protected $t$ test using the Least-Significant Difference procedure of SAS. All data are expressed as treatment means \pm SEM.

\section{Results}

$R S D$-induced anxiety-like behavior was paralleled by an increased percentage of circulating monocytes $\left(C D 11 b^{+} / S S C^{l o} / L^{2} 6 C^{\text {hi }}\right)$ and macrophages $\left(C D 11 b^{+} / C D 45^{h i}\right)$ in the brain

We have reported that RSD promotes anxiety-like behavior, activates microglia, and increases the percentage of macrophages associated with the brain (Wohleb et al., 2011, 2012). Therefore, the purpose of this study was to determine the degree to which RSD-induced anxiety was dependent on the influx of macrophages to the brain. In the first experiment, anxiety-like behavior was determined after one, three, or six cycles of social defeat. Figure 1 shows that anxiety-like behavior developed after three cycles of social defeat with increased time to enter the center of the open field $\left(F_{(3,33)}=3.67, p<0.02\right.$; Fig. $\left.1 A\right)$ and reduced time spent in the center of the open field $\left(F_{(3,33)}=3.19, p<0.04\right.$; Fig. $1 B)$. Anxiety-like behavior in the open-field test was not present after one cycle of social defeat, but was apparent after three and six cycles of social defeat $(p<0.05$, for each). Stress-induced anxiety-like behavior was also detected using the light-dark preference test (Fig. $1 C, D$ ) with decreased time to enter the dark zone $\left(F_{(3,32)}=2.25, p=0.10\right.$; Fig. $\left.1 C\right)$ and decreased time spent in the light zone $\left(F_{(3,32)}=3.82, p<0.02\right.$; Fig. $\left.1 D\right)$ compared with controls. Concomitant with anxiety-like behavior, repeated cycles of social defeat increased the percentage of total CD11 ${ }^{+}$ cells in circulation $\left(F_{(3,30)}=8.62, p<0.0003\right.$; Fig. $\left.1 E, F\right)$ due to robust increases in $\mathrm{CD}_{11 \mathrm{~b}}{ }^{+} / \mathrm{SSC}^{\text {hi }} / \mathrm{Ly} 6 \mathrm{C}^{\text {int }}$ granulocytes $\left(F_{(3,30)}=\right.$ 5.08, $p<0.006$; Fig. $1 E, G)$ and $\mathrm{CD}_{11 \mathrm{~b}}{ }^{+} / \mathrm{SSC}^{\text {lo }} / \mathrm{Ly}_{6 \mathrm{C}} \mathrm{hi}^{\text {mono- }}$ cytes $\left(F_{(3,30)}=10.62, p<0.0001\right.$; Fig. $\left.1 E, H\right)$. It is important to point out that RSD did not increase other myeloid cell populations, including Ly6C ${ }^{-}$monocytes (Geissmann et al., 2003; Hanna et al., 2011). In addition, RSD increased the proportion of $\mathrm{CD} 11 \mathrm{~b}{ }^{+} / \mathrm{CD} 45^{\text {hi }}$ myeloid cells in the brain $\left(F_{(3,33)}=4.95, p<\right.$ 0.007 ; Fig. $1 G, H)$. The majority of $\mathrm{CD} 11 \mathrm{~b}^{+} / \mathrm{CD} 45^{\text {hi }}$ cells were determined to be monocyte-derived macrophages because they exhibit low side-scatter properties similar to peripheral monocytes (Fig. 1I). In each case, there was an increase after three and six cycles of RSD ( $p<0.06$, for each). Therefore, cycledependent development of anxiety with RSD coincided with an increased percentage of circulating monocytes and an enhanced proportion of macrophages associated with the brain.
Table 1. IL-1 $\beta$ and CCL2 mRNA expression were increased in the CTX-R, HYPO, BG, and HPC immediately following RSD ${ }^{a}$

\begin{tabular}{lllll}
\hline Region: gene & Control & RSD (1 cycle) & RSD (3 cycles) & RSD (6 cycles) \\
\hline CTX-R: & & & & \\
IL-1 $\beta$ & $1.02 \pm 0.08$ & $0.99 \pm 0.06$ & $1.53 \pm 0.18^{*}$ & $1.73 \pm 0.17^{*}$ \\
CCL2 & $1.01 \pm 0.05$ & $0.87 \pm 0.06$ & $1.71 \pm 0.43^{\#}$ & $2.30 \pm 0.24^{*}$ \\
CX $C$ CL1 & $1.01 \pm 0.06$ & $0.98 \pm 0.02$ & $0.86 \pm 0.02^{*}$ & $0.88 \pm 0.05^{*}$ \\
HYP0: & & & & \\
IL-1 $\beta$ & $1.16 \pm 0.13$ & $2.83 \pm 0.93^{\#}$ & $2.59 \pm 0.63^{\#}$ & $4.85 \pm 1.22^{*}$ \\
CCL2 & $1.05 \pm 0.12$ & $1.67 \pm 0.65$ & $1.40 \pm 0.61$ & $5.44 \pm 2.48^{*}$ \\
CX $C$ CL1 & $1.17 \pm 0.18$ & $1.27 \pm 0.26$ & $0.57 \pm 0.06^{*}$ & $0.68 \pm 0.14^{\#}$ \\
BG: & & & & \\
IL-1 $\beta$ & $1.01 \pm 0.05$ & $1.70 \pm 0.20$ & $4.04 \pm 0.78^{*}$ & $4.81 \pm 0.77^{*}$ \\
CCL2 & $1.03 \pm 0.12$ & $0.95 \pm 0.10$ & $1.43 \pm 0.24$ & $3.76 \pm 1.24^{*}$ \\
CX CL1 & $1.01 \pm 0.06$ & $1.05 \pm 0.05$ & $0.87 \pm 0.05^{\#}$ & $0.95 \pm 0.01$ \\
HPC: & & & & \\
IL-1 $\beta$ & $1.05 \pm 0.14$ & $1.90 \pm 0.31$ & $3.89 \pm 0.74^{*}$ & $5.19 \pm 0.82^{*}$ \\
CCL2 & $1.03 \pm 0.11$ & $1.16 \pm 0.13$ & $1.63 \pm 0.23$ & $3.36 \pm 0.57^{*}$ \\
CX ${ }_{3}$ CL1 & $1.01 \pm 0.07$ & $1.06 \pm 0.04$ & $1.01 \pm 0.04$ & $0.99 \pm 0.05$ \\
\hline
\end{tabular}

${ }^{a}$ Male C57BL/6 mice were subjected to one, three, or six cycles of social defeat (RSD) or left undisturbed as controls. Immediately following the final cycle of RSD, brains were removed, dissected, and frozen in liquid nitrogen. IL- $1 \beta$ $C \mathrm{CL} 2$, and $\mathrm{CX}_{3} \mathrm{CL} 1 \mathrm{mRNA}$ levels were determined in the CTX-R, HYPO, BG, and HPC $(n=4-6,2$ independent experiments). Values represent average fold change compared to control. Means with asterisk $(*)$ are significantly different from controls $(p<0.05)$ and means with number sign (\#) are different from controls $(p<0.10)$.

$I L-1 \beta$ and CCL2 $m R N A$ expression were increased in the cortex, hypothalamus, basal ganglia, and hippocampus following RSD Repeated exposure to social defeat increased the percentage of monocytes $\left(\mathrm{CD}_{11} \mathrm{~b}^{+} / \mathrm{SSC}^{\mathrm{lo}} / \mathrm{Ly}_{6} \mathrm{C}^{\text {hi }}\right)$ in circulation and macrophages $\left(\mathrm{CD} 11 \mathrm{~b}^{+} / \mathrm{SSC}^{\mathrm{lo}} / \mathrm{CD} 45^{\mathrm{hi}}\right)$ in the brain (Fig. 1). Recruitment of peripheral myeloid cells to the brain is associated with induction of proinflammatory cytokines (e.g., IL-1 $\beta$ ) and chemokines, including chemokine ligand-2 (CCL2) and fractalkine $\left(\mathrm{CX}_{3} \mathrm{CL} 1\right.$; Ching et al., 2007; Prinz and Priller, 2010). Therefore, IL-1 $\beta$, CCL2, and $\mathrm{CX}_{3} \mathrm{CL} 1 \mathrm{mRNA}$ levels were determined immediately after the final cycle of RSD in the rostral cortex (CTX-R), hypothalamus (HYPO), basal ganglia (BG), and hippocampus (HPC). These regions were selected because the CTX-R includes the prefrontal cortex (PFC), the HYPO includes the paraventricular nucleus (PVN), and the BG includes the amygdala (AMYG), lateral septum (LS), bed nucleus of the stria terminalis (BNST), and nucleus accumbens. These brain regions are implicated in fear and anxiety responses (Ressler and Mayberg, 2007; Shin and Liberzon, 2010) and have increased microglia and neuronal activation following RSD (Wohleb et al., 2011).

Table 1 shows that RSD increased IL- $1 \beta$ mRNA expression in the CTX-R, HYPO, BG, and HPC. In each region, increased IL- $1 \beta$ mRNA expression was dependent on the number of RSD cycles $(p<0.03$, for each). RSD also increased CCL2 mRNA expression in the CTX-R, BG, and HPC ( $p<0.03$, for each). $\mathrm{CX}_{3} \mathrm{CL} 1$ mRNA expression was reduced in the CTX-R and HYPO by RSD ( $p<0.05$, for each). $\mathrm{CX}_{3} \mathrm{CL} 1 \mathrm{mRNA}$ was also reduced in the $\mathrm{BG}$ after three cycles of $\mathrm{RSD}$, but returned to baseline levels by six cycles of RSD. Collectively, these data indicate that RSD promoted a cycle-dependent increase in IL- $1 \beta$ and CCL2 mRNA and a selective decrease in CX $_{3}$ CL1 mRNA in brain regions associated with anxiety and microglia activation.

$R S D$-induced anxiety was associated with increased recruitment of LysM-GFP ${ }^{+}$monocytes from circulation into the brain

To continue to investigate the role of peripheral monocytes in RSD-induced anxiety-like behavior, heterozygous LysM-GFP ${ }^{+}$ mice were used. These mice have GFP expressed on the lysozyme M (LysM) promoter. In this model, peripheral myeloid cells (monocytes and granulocytes) are $\mathrm{LysM}^{+} / \mathrm{GFP}^{+}$(Faust et al., 
A

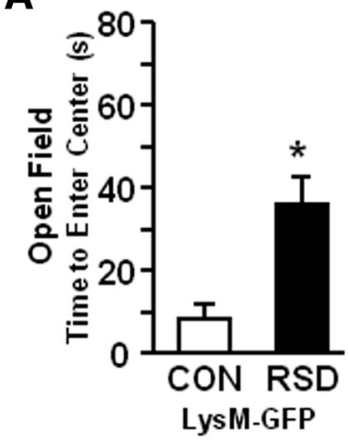

D

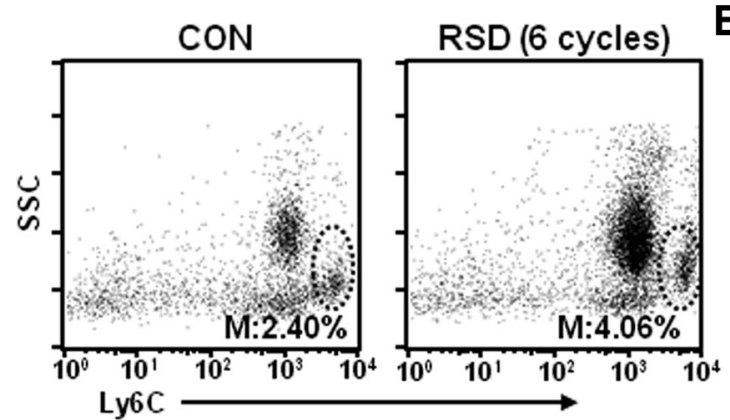

B

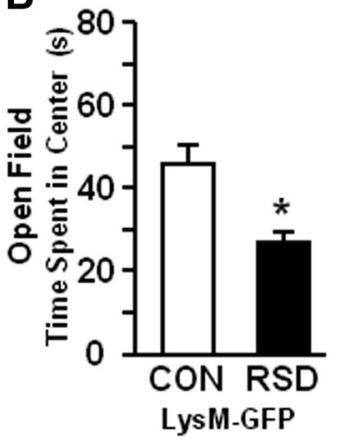

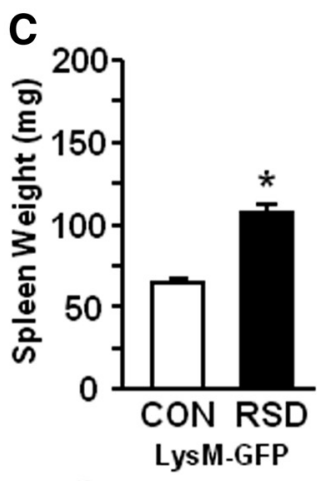

E

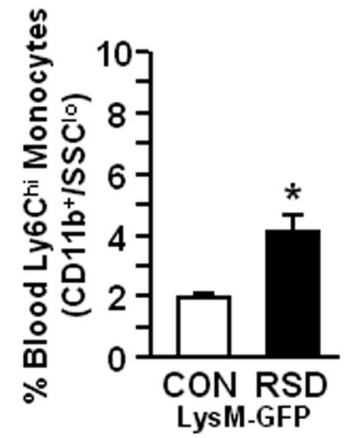

F

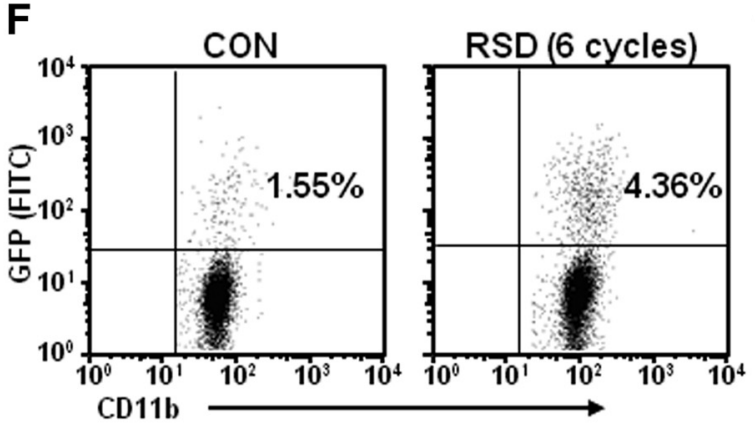

G

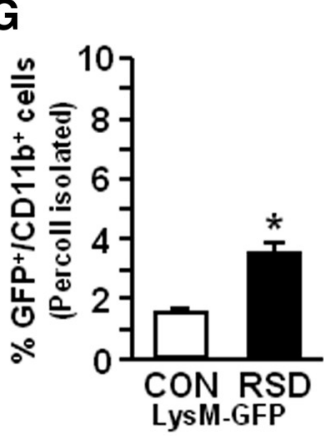

$\mathbf{H}$

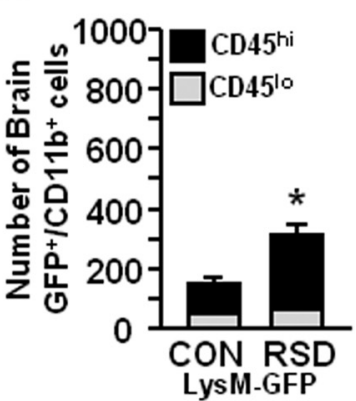

I
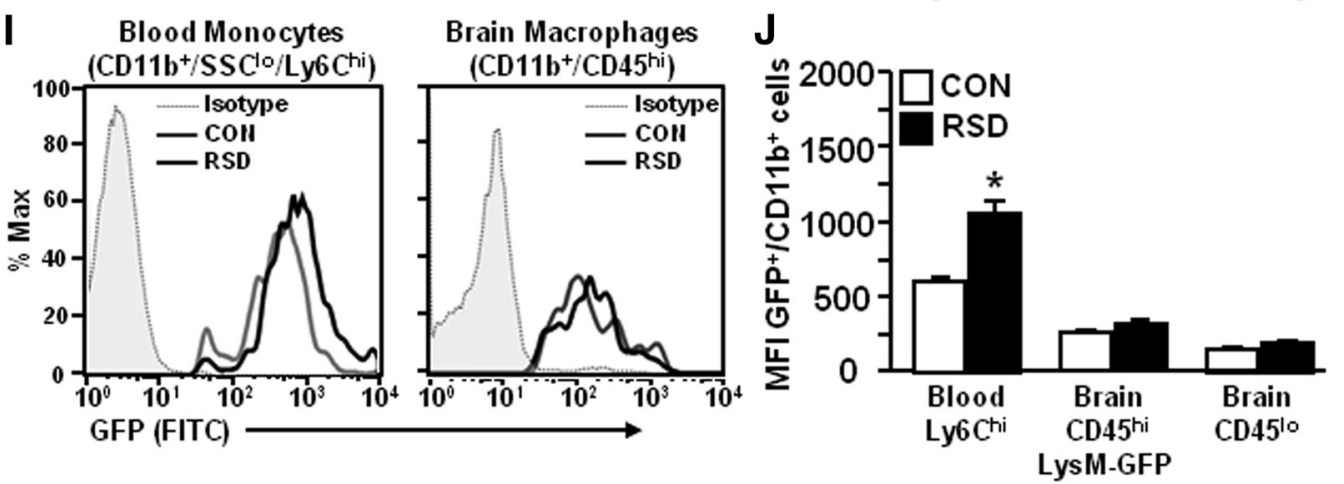

Figure 2. RSD-induced anxiety was associated with increased recruitment of LySM-GFP ${ }^{+}$monocytes from circulation into the brain. LysM-GFP ${ }^{+}$mice were subjected to six cycles of social defeat (RSD) or left undisturbed as controls (CON). Anxiety-like behavior was tested $14 \mathrm{~h}$ after RSD. Following behavioral testing, blood and enriched brain CD 11b ${ }^{+}$cells were collected ( $n=6-8,2$ independent experiments). $\boldsymbol{A}$, Time to enter the center of the open field. $\boldsymbol{B}$, Time spent in the open field. $\boldsymbol{C}$, Average spleen weight. $\boldsymbol{D}$, Representative flow bivariate dot plots of SSC/Ly6C on CD11b + cells. $\boldsymbol{E}$, The percentage of

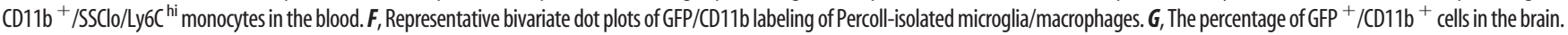

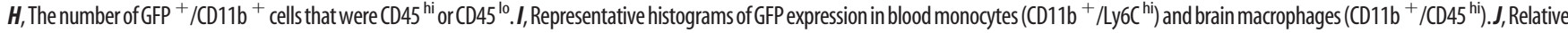
$\mathrm{MFl}$ of GFP ${ }^{+} / \mathrm{CD}_{11 \mathrm{~b}^{+}}{ }^{+}$cells in the blood or brain. Bars represent the mean \pm SEM. Means with asterisk are significantly different from $\mathrm{CON}(p<0.05)$.

2000), but resident microglia are $\mathrm{GFP}^{-}$(Kim et al., 2009). In these experiments, LysM-GFP ${ }^{+}$mice were subjected to RSD (six cycles) and $14 \mathrm{~h}$ later anxiety-behavior was determined. Figure $2 A, B$ shows that RSD caused anxiety-like behavior in LysM$\mathrm{GFP}^{+}$mice with increased time to enter the open field $(p<0.04$; Fig. $2 A)$ and decreased total time spent in the open field $(p<$
0.005; Fig. 2B). After completion of behavioral testing, spleen weight, blood, and brains were collected. Consistent with previous findings (Fig. 1), RSD increased spleen weight $(p<0.01$; Fig. $2 C)$ and increased the proportion of monocytes (CD11b ${ }^{+} / \mathrm{SSC}^{\mathrm{lo}} /$ Ly6C $\left.{ }^{\text {hi }}\right)$ in circulation of LysM-GFP ${ }^{+}$mice $(p<0.01$; Fig. $2 D, E)$. It is important to point out that Ly6 $\mathrm{C}^{\text {hi }}$ monocytes were 

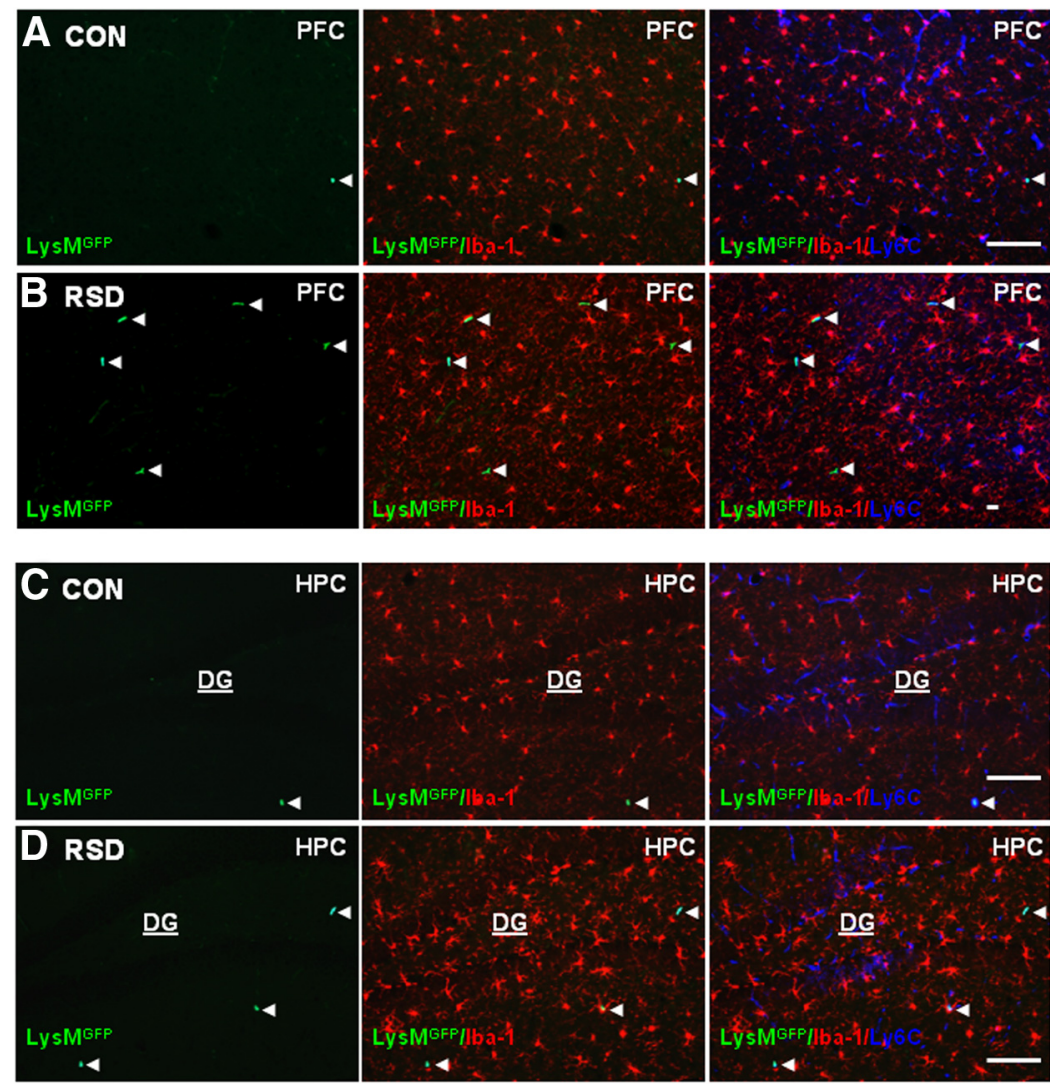

Figure 3. LysM-GFP ${ }^{+}$macrophages were present in the PVS of the brain following RSD. LysM-GFP ${ }^{+}$mice were subjected to six cycles of social defeat (RSD) or left undisturbed as controls (CON). Brains were collected $14 \mathrm{~h}$ after RSD for histology ( $n=4-6,2$ independent experiments). $\boldsymbol{A}, \boldsymbol{B}$, Representative images of Lys $\mathrm{M}^{\text {GFP }}$ (green), merged Lys $\mathrm{M}^{\mathrm{GFP}} / \mathrm{Iba}-1$ (red), and merged Lys $\mathrm{M}^{\mathrm{GFP}} /$ Iba-1/Ly6C (blue) in the PFC of CON and RSD mice. C, D, Representative images of LysM ${ }^{\text {GFP }}$ (green), merged LysM ${ }^{\text {GFP }} / \mathrm{lba}$ - 1 (red), and merged LysM $\mathrm{M}^{\mathrm{GFP}} / \mathrm{lba}-1 / \mathrm{Ly} 6 \mathrm{C}$ (blue) immunofluorescence in the HPC of CON and RSD mice. White arrowheads point to perivascular LysM-GFP ${ }^{+}$macrophages. Scale bars, $100 \mu \mathrm{m}$.

$\sim 98 \% \mathrm{GFP}^{+}$in LysM-GFP ${ }^{+}$mice (data not shown). Moreover, RSD increased the percentage of $\mathrm{LysM}-\mathrm{GFP}^{+} / \mathrm{CD}_{11 \mathrm{~b}}{ }^{+}$cells in the brain $(p<0.002$; Fig. $2 F, G)$. Analyses of $\mathrm{GFP}^{+} / \mathrm{CD} 11 \mathrm{~b}^{+}$ cells based on side-scatter properties showed that the majority of brain $\mathrm{GFP}^{+} / \mathrm{CD} 11 \mathrm{~b}^{+}$cells had characteristics of monocytes/ macrophages (data not shown). Thus, the increased proportion of $\mathrm{GFP}^{+} / \mathrm{CD} 1 \mathrm{~b}^{+}$cells resulted in a doubling of GFP ${ }^{+}$macrophages $\left(\mathrm{CD} 11 \mathrm{~b}^{+} / \mathrm{CD} 45^{\mathrm{hi}} ; p<0.01\right)$, but no change in the number of $\mathrm{GFP}^{+} / \mathrm{CD} 1 \mathrm{~b}^{+}$cells that had low expression of CD45 (Fig. $2 \mathrm{H}$ ). Representative histograms of GFP mean fluorescence intensity (MFI) are shown for blood monocytes $\left(\mathrm{CD}_{11 \mathrm{~b}}{ }^{+} / \mathrm{SSC}^{\mathrm{lo}} /\right.$ Ly6C $\left.{ }^{\text {hi }}\right)$ and brain CD $11 b^{+}$cells $\left(\mathrm{CD} 45^{\text {hi }}\right.$ or CD $45^{\text {lo }}$; Fig. $\left.2 I, J\right)$. Figure $2 J$ shows that RSD increased the GFP MFI for Ly6C ${ }^{\text {hi }}$ monocytes in the blood compared with controls $(p<0.002)$. There was no significant difference in MFI of GFP in brain $\mathrm{CD}_{11} \mathrm{~b}^{+}$cells between RSD and control mice. It is relevant to highlight, however, that MFI for GFP was markedly reduced in brain $\mathrm{CD} 11 \mathrm{~b}^{+}$cells compared with monocytes in circulation (Fig. $2 J$ ). Collectively, these data indicate that RSD-induced anxiety was associated with the recruitment of peripheral monocytes to the brain.

\section{LysM-GFP ${ }^{+}$macrophages were present in the PVS of the brain} following RSD

Next, LysM-GFP ${ }^{+}$mice were subjected to RSD and brains were collected to determine the presence of $\mathrm{GFP}^{+}$cells in the brain. Resident microglia (Iba- ${ }^{+}$, red) and endothelial cells (Ly6C, blue) were also labeled in the same brain sections. Representative images of GFP, merged GFP/Iba-1, or merged GFP/Iba1/Ly6C immunofluorescence in RSD and control mice are shown in the PFC (Fig. $3 A, B$ ) and dentate gyrus (DG) of the HPC (Fig. $3 C, D$ ). Images in the PFC (Fig. $3 A$ ) and DG (Fig. $3 C$ ) of control mice showed that there were few LysM-GFP ${ }^{+}$cells in the brain. Figure 3 shows that the majority of LysM-GFP ${ }^{+}$cells in control and RSD mice were perivascular macrophages with rod/circular morphology, low expression of Iba-1, and colocalization with the vasculature (Ly6C). In LysM-GFP ${ }^{+}$mice subjected to $\mathrm{RSD}, \mathrm{GFP}^{+}$perivascular macrophages were increased in the PFC (Fig. 3B) and DG (Fig. 3D) compared with controls. Corresponding with the increased presence of LysM-GFP ${ }^{+}$perivascular macrophages in the PFC and DG of RSD mice, resident microglia (Iba- $1^{+} / \mathrm{GFP}^{\text {neg }}$ ) had a deramified morphology (Fig. 3B,D) compared with controls (Fig. $3 A, C$ ). Together, these findings show that RSD enhanced microglial activation in the PFC and DG and increased recruitment of peripheral LysM-GFP ${ }^{+}$ macrophages to the brain PVS.

\section{Peripheral GFP ${ }^{+} / \mathrm{CD} 11 b^{+}$macrophages were recruited into the brain of $G F P^{+}$}

$B M$-chimeric mice after RSD

Based on results from LysM-GFP ${ }^{+}$mice it was evident that RSD promoted recruitment of BM-derived $\mathrm{GFP}^{+}$monocytes to the brain (Fig. 2) and these cells entered the PVS as $\mathrm{GFP}^{+}$macrophages (Fig. 3). Because GFP MFI was reduced in brain $\mathrm{CD} 1 \mathrm{~b}^{+}$cells compared with circulating monocytes (Fig. $2 \mathrm{~J}, \mathrm{~K}$ ) and resident microglia did not express GFP in LysM-GFP ${ }^{+}$mice, it was possible that LysM expression on myeloid cells was downregulated in the brain (Cross et al., 1988). Thus, our results from LysM-GFP ${ }^{+}$mice may underestimate the extent to which RSD promotes macrophage recruitment in the brain. Therefore, $\mathrm{GFP}^{+} \mathrm{BM}$-chimera mice were generated with BM-derived donor cells that ubiquitously express GFP. In this model, macrophage recruitment following RSD can be examined because resident $\left(\mathrm{GFP}^{-}\right)$and $\mathrm{BM}$-derived cells $\left(\mathrm{GFP}^{+}\right)$can be distinguished based on GFP expression. Four weeks after BM reconstitution, $\mathrm{GFP}^{+} \mathrm{BM}$-chimeric mice were subjected to RSD or left undisturbed as controls and enriched brain $\mathrm{CD} 11 \mathrm{~b}^{+}$cells were collected $14 \mathrm{~h}$ after RSD to examine the percentage of GFP ${ }^{+}$ macrophages associated with the brain. As expected, RSD increased the proportion of $\mathrm{GFP}^{+} / \mathrm{CD}_{11 \mathrm{~b}}{ }^{+}$cells in the brain of $\mathrm{GFP}^{+} \mathrm{BM}$-chimeric mice compared with controls $(p<0.05$; Fig. $4 A, B)$. Similar to LysM-GFP ${ }^{+}$cells, brain $\mathrm{GFP}^{+} / \mathrm{CD}_{11 \mathrm{~b}}{ }^{+}$cells had low side-scatter properties consistent with monocytes/macrophages (data not shown). Moreover, RSD tended to increase the number of $\mathrm{GFP}^{+} / \mathrm{CD} 11 \mathrm{~b}^{+} / \mathrm{CD} 45^{\text {lo }}$ cells in the brain $(p=0.10)$ and markedly increased the number of $\mathrm{GFP}^{+} / \mathrm{CD} 11 \mathrm{~b}^{+} / \mathrm{CD} 45^{\text {hi }}$ cells in the brain of $\mathrm{GFP}^{+} \mathrm{BM}$-chimeric mice $(p<0.04$, Fig. $4 C)$. These data indicate that RSD increased the proportion and number of peripheral GFP ${ }^{+}$macrophages associated with the brain. 
Another cohort of $\mathrm{GFP}^{+} \mathrm{BM}$-chimeric mice were subjected to RSD (six cycles) and brains were collected for histology $14 \mathrm{~h}$ after the final cycle. Peripheral macrophages $\left(\mathrm{GFP}^{+}\right.$, green), microglia (Iba$1^{+}$, red) and endothelial cells (Ly6C ${ }^{+}$, blue) were identified with immunofluorescence. Representative images of GFP, merged GFP/Iba-1, and merged GFP/Iba1/Ly6C immunofluorescence are shown in the HPC of control (Fig. 4D) and RSD mice (Fig. 4E). Images from control mice show that there were few perivascular $\mathrm{GFP}^{+}$macrophages present in the HPC (Fig. 4D). In contrast, $\mathrm{GFP}^{+} \mathrm{BM}-$ chimeric mice subjected to RSD had increased BM-derived macrophages in the PVS and in the parenchyma $\left(\mathrm{GFP}^{+} /\right.$ Iba- ${ }^{+}$with ramified phenotype; Fig. $4 E$ ). These images show that the presence of parenchymal GFP ${ }^{+}$macrophages in the HPC of RSD mice also corresponded with increased Iba-1 immunoreactivity in the resident microglial $\left(\mathrm{Iba}-1^{+} /\right.$ $\mathrm{GFP}^{-}$) population.

Because RSD promoted robust macrophage recruitment into the HPC of GFP ${ }^{+}$ BM-chimeric mice, blood-brain barrier (BBB) permeability was assessed. Figure $4 F$ shows that intraocular injury $[(+)$ Control] increased the permeability of Evans blue dye throughout the brain (inset) and specifically in the HPC (red background). Mice subjected to RSD (six cycles; Fig. $4 G$ ) or treated with busulfan regimen (Fig. $4 H$ ) did not have increased the permeability to Evans blue dye. Thus, RSD caused significant macrophage recruitment into the brain of $\mathrm{GFP}^{+} \mathrm{BM}-$ chimeric mice that was not associated with generalized BBB permeability.

RSD promoted infiltration of peripheral macrophages (ramified $\mathrm{GFP}^{+} / \mathrm{Iba}-1^{+}$) into the parenchyma of brain regions associated with fear and anxiety

Based on the results shown in Figure 4, the neuroanatomical distribution of $\mathrm{GFP}^{+}$macrophages was determined in control and socially defeated mice. Representative images of $\mathrm{GFP}^{+}$macrophages in the PFC (Fig. 5A,B) and AMYG (Fig. 5C,D) of control and RSD mice are shown. As previously noted, perivascular $\mathrm{GFP}^{+}$macrophages were present in control mice, but the number of parenchymal GFP ${ }^{+}$macrophages was limited (Fig. 5A,C). $\mathrm{GFP}^{+} \mathrm{BM}$-chimeric mice subjected to RSD had significant infiltration of $\mathrm{GFP}^{+}$macrophages into the parenchyma of the PFC and AMYG (Fig. 5B,D). Parenchymal $\mathrm{GFP}^{+}$macrophages were predominantly detected in brain regions associated with fear and anxiety responses, including the HPC, PFC, and AMYG (Figs. 4, 5). Exposure to RSD also promoted recruitment of parenchymal $\mathrm{GFP}^{+}$macrophages into the olfactory bulb, PVN, LS, BNST, nucleus accumbens, and piriform cortex (data not shown). RSDinduced infiltration of $\mathrm{GFP}^{+}$macrophages into the parenchyma, however, was not detected in the primary motor cortex (M1 CTX;
Fig. 5E), striatum, somatosensory cortex, and cerebellum (data not shown).

Quantification of perivascular and parenchymal GFP ${ }^{+}$macrophages showed that RSD increased the total number of GFP ${ }^{+}$ macrophages in the $\operatorname{PFC}\left(F_{(3,19)}=9.43, p<0.0008\right), \operatorname{PVN}\left(F_{(3,19)}=\right.$ $10.91, p<0.0004), \operatorname{AMYG}\left(F_{(3,19)}=5.46, p<0.009\right)$, and HPC $\left(F_{(3,19)}=5.92, p<0.006\right.$; Fig. $\left.6 A-E\right)$. Repeated cycles of social defeat caused significant infiltration of peripheral macrophages $\left(\mathrm{GFP}^{+} / \mathrm{Iba}^{+}{ }^{+}\right.$ramified $)$into the parenchyma of $\mathrm{PFC}\left(F_{(3,19)}=\right.$ 9.45, $p<0.0008)$, PVN $\left(F_{(3,19)}=5.67, p<0.008\right)$, AMYG $\left(F_{(3,19)}=4.90, p<0.01\right)$, and $\operatorname{HPC}\left(F_{(3,19)}=10.73, p<0.0004\right)$. In addition, RSD increased the number of perivascular ( $\mathrm{rod} / \mathrm{cir}$ cular) $\mathrm{GFP}^{+}$macrophages in the PFC, PVN, AMYG, and HPC $\left(p<0.01\right.$, for each region). The number of $\mathrm{GFP}^{+}$macrophages was also determined separately in the CA1, CA2, CA3, and DG of the HPC (Fig. 6E). The majority of $\mathrm{GFP}^{+}$parenchymal macrophages present in the HPC after RSD (Fig. 6D) were located in the CA3 and DG (Fig. 6E; $p<0.003$, for each). Figure $6 F$ shows a representative illustration of the brain regions with parenchymal 


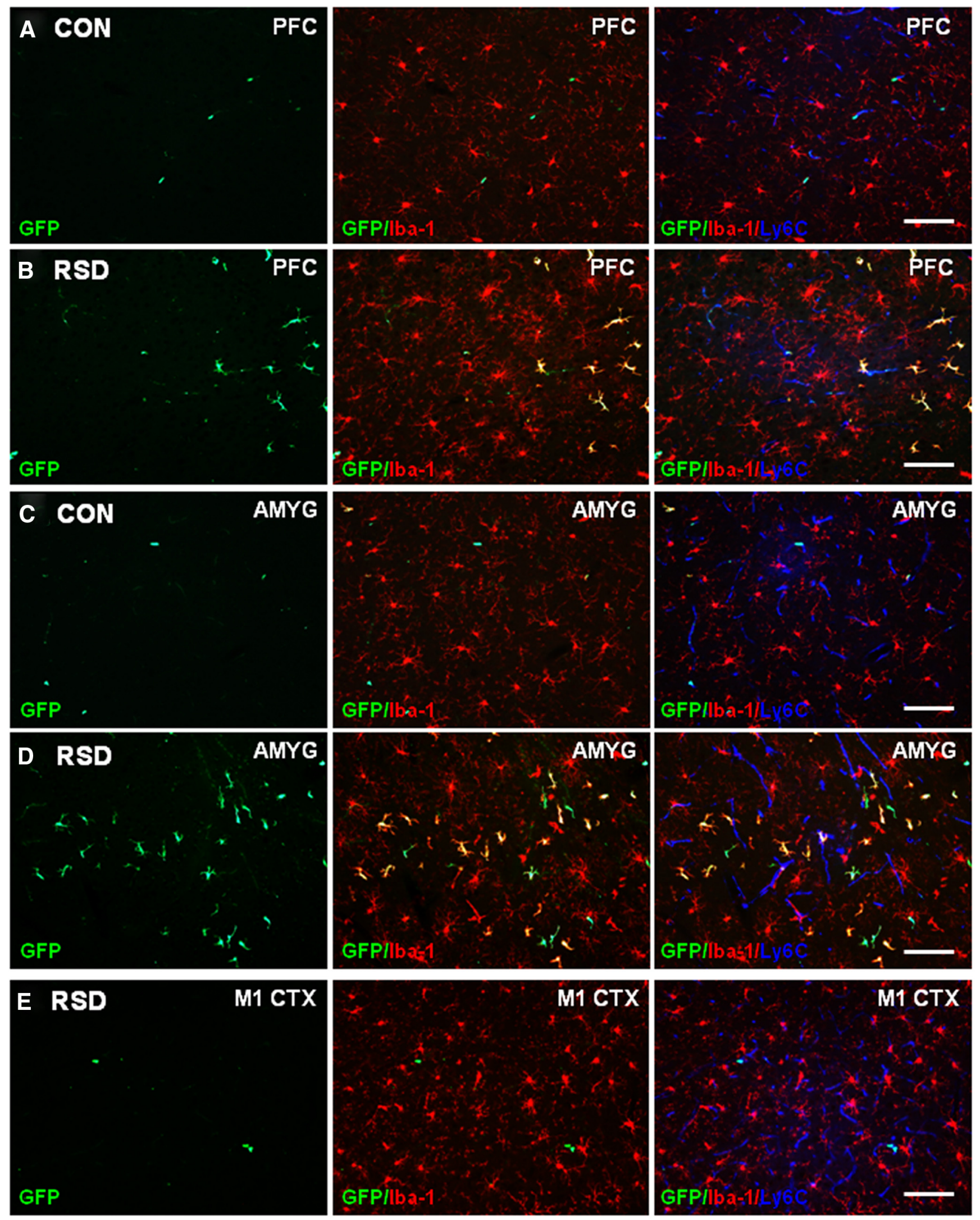

Figure 5. RSD promoted infiltration of peripheral macrophages (ramified GFP ${ }^{+} / \mathrm{lba}-1^{+}$) into the parenchyma of brain regions associated with fear and anxiety. GFP ${ }^{+}$BM-chimeric mice were subjected to six cycles of social defeat (RSD) or left undisturbed as controls (CON). The neuroanatomical distribution of GFP ${ }^{+}$cells was determined $14 \mathrm{~h}$ after the final cycle of RSD $(n=3-4)$. $\boldsymbol{A}, \boldsymbol{B}$, Representative images of GFP (green), merged GFP/lba-1 (red), and merged GFP//ba-1/Ly6C (blue) immunofluorescence in the PFC of CON and RSD mice. C, D, Representative images of GFP (green), merged GFP/lba-1 (red), and merged GFP/lba-1/Ly6C (blue) immunofluorescence in the AMYG of CON and RSD mice. E, Representative images of GFP (green), merged GFP/lba-1 (red), and merged GFP/lba-1/Ly6C (blue) immunofluorescence in the M1 CTX of RSD mice. Scale bars, $100 \mu \mathrm{m}$. 
infiltration of $\mathrm{GFP}^{+}$macrophages (darker gray) in control and socially defeated mice. Together, social defeat promoted the recruitment of BM-derived macrophages into the parenchyma of specific brain regions associated with fear and anxiety in $\mathrm{GFP}^{+} \mathrm{BM}$-chimeric mice.

$R S D$ increased the proportion of circulating CD $11 b^{+} / S S C^{l o} / L y 6 C^{h i}$ monocytes independent of CCR 2 and $C X_{3}$ CR1 expression

Our data indicated that development of anxiety-like behavior after RSD was paralleled by increased myeloid cells in circulation and in the brain (Figs. 1-3). In addition, RSD influenced chemokine mRNA expression (CCL2 and $\mathrm{CX}_{3} \mathrm{CL} 1$ ) in both a brain region-dependent and cycle-dependent manner (Table 1). The corresponding receptors for these chemokines, CCR2 and $\mathrm{CX}_{3} \mathrm{CR} 1$, are important for monocyte recruitment to the brain. Therefore, WT or CCR $2^{\mathrm{KO}}$ and $\mathrm{CX}_{3} \mathrm{CR} 1^{\mathrm{HET}}$ or $\mathrm{CX}_{3} \mathrm{CR} 1^{\mathrm{KO}}$ mice were subjected to RSD (six cycles). Because RSD-induced myeloid cell trafficking promotes splenomegaly, spleen weight was determined in WT and chemokinereceptor-deficient mice. Figure $7 A$ shows that spleen weight increased after RSD in WT mice, but not in CCR $2{ }^{\mathrm{KO}}$ mice (RSDCCR2 interaction, $F_{(1,35)}=23.89, p<$ $0.0001)$. RSD also increased spleen weight in transgenic $\mathrm{CX}_{3} \mathrm{CR} 1$ mice $\left(F_{(1,40)}=\right.$ 24.06, $p<0.0001)$ and this was independent of genotype. Figure $7 B$ shows that RSD increased the proportion of myeloid cells $\left(\mathrm{CD} 11 \mathrm{~b}^{+}\right)$in the blood of each group $(p<0.0001$, for each). In addition, Figure $7 C, D$ shows that the percentage of monocytes $\left(\mathrm{CD} 11 \mathrm{~b}^{+} / \mathrm{SS}\right.$ $\mathrm{C}^{\text {lo }} / \mathrm{Ly} 6 \mathrm{C}^{\text {hi }}$ ) in the blood was increased after RSD in WT and CCR $2{ }^{\mathrm{KO}}$ mice $\left(F_{(1,21)}=21.41, p<0.0002\right)$ and in $\mathrm{CX}_{3} \mathrm{CR} 1^{\mathrm{HET}}$ and $\mathrm{CX}_{3} \mathrm{CR} 1^{\mathrm{KO}}$ mice $\left(F_{(1,11)}=20.79, p<0.002\right)$. Thus, RSD enhanced the proportion of circulating monocytes independent of CCR2 and $\mathrm{CX}_{3} \mathrm{CR} 1$ expression.

$R S D$ increased IL-1 $\beta$ mRNA expression in the CTX-R, HYPO, $B G$, and $H P C$ independent of CCR 2 or $C X_{3} C R 1$ genotype Our previous data and Table 1 show that RSD-induced myeloid cell trafficking to the brain was associated with increased IL-1 $\beta$ mRNA levels (Wohleb et al., 2011, 2012). Based on these data it is plausible that peripheral myeloid cells initiate stressinduced IL- $1 \beta$ signaling. To determine if myeloid cell trafficking was required for increased IL- $1 \beta$ expression, brains were collected from WT or CCR2KO and CX3CR1HET or CX3CR1KO mice and mRNA levels were determined in the CTX-R, HYPO, BG, and HPC at $14 \mathrm{~h}$ after the final cycle of RSD. Table 2 shows that RSD increased IL- $1 \beta$ mRNA expression in the CTX-R $\left(F_{(1,37)}=15.77, p<0.0004\right)$, HYPO

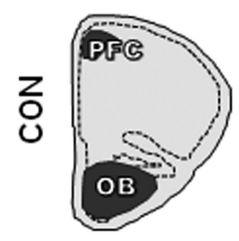
ventricle; Pir, piriform cortex.
B

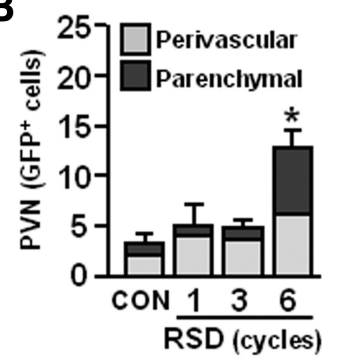

C

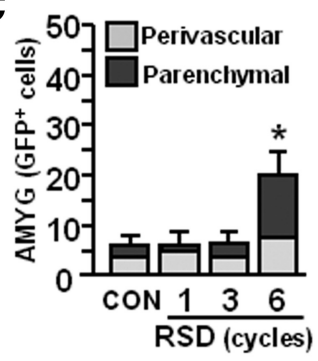

E

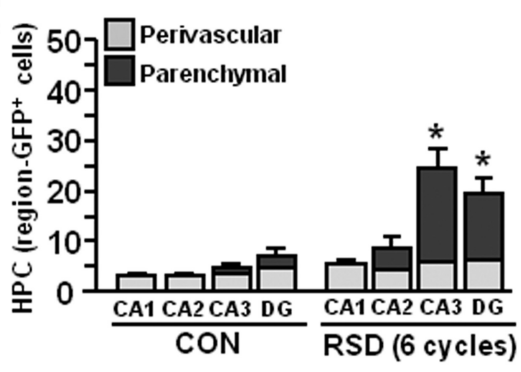

F $\square$ Region with no parenchymal $\mathrm{GFP}^{+}$cells

$\square$ Region with parenchymal $\mathrm{GFP}^{+}$cells
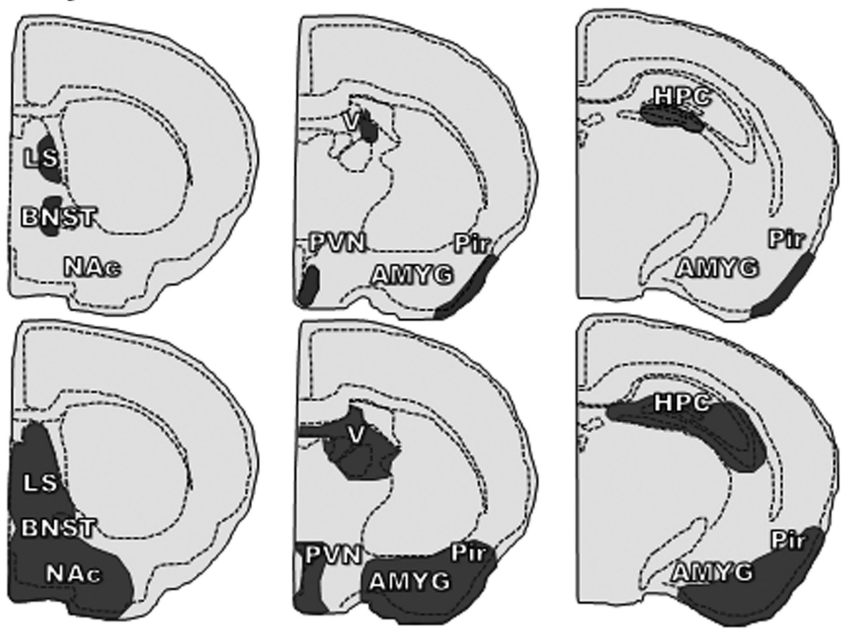

Figure 6. Recruitment of ramified $\mathrm{GFP}^{+}$macrophages in the brain required repeated cycles of RSD. GFP ${ }^{+}$BM-chimeric mice were subjected to one, three, or six cycles of social defeat (RSD) or left undisturbed as controls (CON). The neuroanatomical Quantification of the total number of perivascular and parenchymal GFP ${ }^{+}$cells in the PFC (A), PVN (B), AMYG (C), and HPC (D). $\boldsymbol{E}$, Region-specific quantification of the HPC (CA1, CA2, CA3, and DG) is shown. Bars represent the mean $\pm S E M$. Means with asterisk $0.06-0.10)$. $F$, Representative illustration of $\mathrm{GFP}^{+}$cell distribution throughout the brain following RSD. Areas in dark gray indicate significant distribution of ramified $\mathrm{GFP}^{+}$macrophages. OB, Olfactory bulb; NAc, nucleus accumbens; $V$, dorsal lateral

$\left(F_{(1,38)}=22.10, p<0.0001\right), \mathrm{BG}\left(F_{(1,40)}=21.09, p<0.0001\right)$, and $\operatorname{HPC}\left(F_{(1,42)}=25.95, p<0.0001\right)$. In the HYPO, BG, and HPC, increased IL- $1 \beta$ mRNA expression following RSD was independent of genotype. However, in the CTX-R of CCR $2^{\mathrm{KO}}$ and $\mathrm{CX}_{3} \mathrm{CR} 1{ }^{\mathrm{KO}}$ mice, IL- $1 \beta$ mRNA was not significantly elevated compared with their respective controls. These findings indicate that RSD increased IL- $1 \beta$ mRNA expression in the brain independent of either CCR2 or $\mathrm{CX}_{3} \mathrm{CR} 1$ expression.

RSD-induced macrophage recruitment to the brain and anxietylike behavior required expression of CCR 2 and $C X_{3} C R 1$

Accumulation of monocytes in the blood and macrophages in the brain corresponded with the development of anxiety-like behavior in WT mice (Fig. 1). Because CCR2 and $\mathrm{CX}_{3} \mathrm{CR} 1$ are inte- 

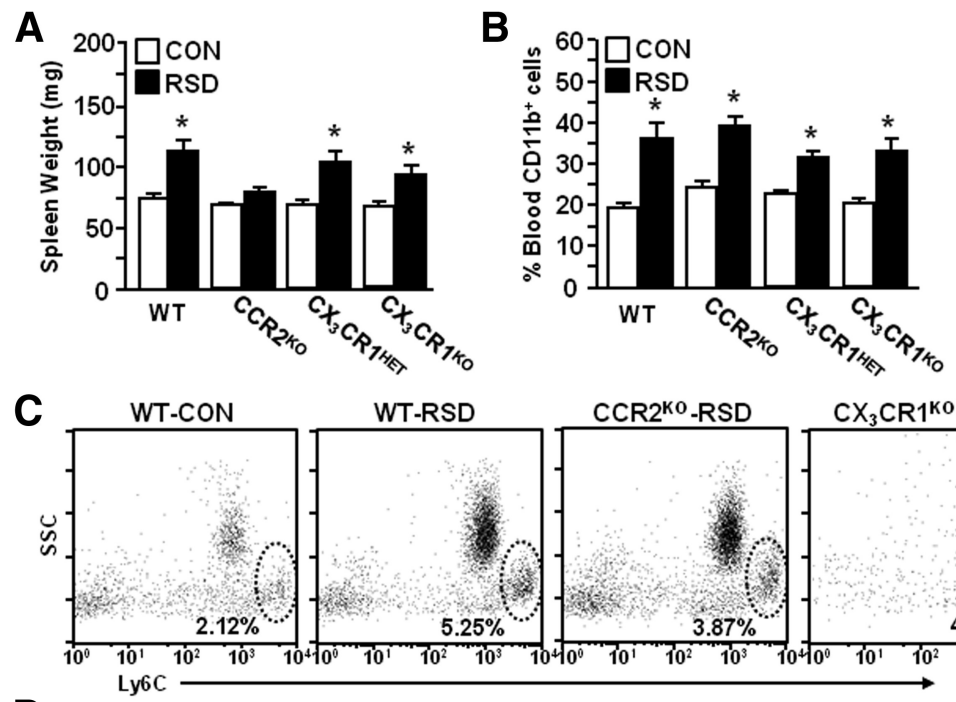

WT-RSD

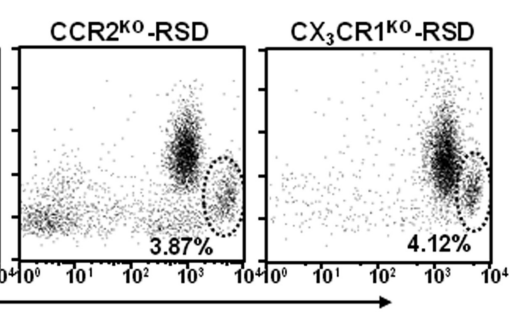

D

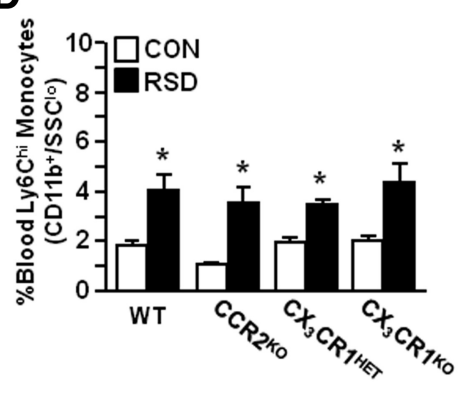

Figure 7. RSD increased the proportion of circulating $\mathrm{CD}_{11 \mathrm{~b}^{+}} / \mathrm{SSC} \mathrm{C}^{\mathrm{l}} / \mathrm{Ly} 6 \mathrm{C}^{\mathrm{hi}}$ monocytes independent of CCR2 and $\mathrm{CX} 3 \mathrm{CR} 1$ expression. In two separate experiments, WT and $\mathrm{CCR}_{2}{ }^{\mathrm{K} 0}$ or $\mathrm{CX}_{3} \mathrm{CR} 1{ }^{\mathrm{HET}}$ and $\mathrm{CX}_{3} \mathrm{CR}^{\mathrm{K} 0}{ }^{\mathrm{K}} \mathrm{C} 7 \mathrm{BL} / 6$ mice were subjected to six cycles of social defeat (RSD) or left undisturbed as controls (CON). Spleens and blood were collected $14 \mathrm{~h}$ after the final cycle of RSD ( $n=$ $3-8,3$ independent experiments). $\boldsymbol{A}$, Average spleen weight. $\boldsymbol{B}$, The percentage of myeloid cells (CD11b ${ }^{+}$) in the blood. $\boldsymbol{C}$, Representative flow bivariate dot plots of Ly6C/CD11b labeling. $D$, The percentage of blood monocytes (CD11b $\left.{ }^{+} / \mathrm{Ly}_{6} \mathrm{C}^{\mathrm{hi}}\right)$. Bars represent the mean \pm SEM. Means with asterisk (*) are significantly different from genotype CON $(p<0.05)$.

gral mediators of monocyte recruitment to the brain, WT, CCR2 $2^{\mathrm{KO}}, \mathrm{CX}_{3} \mathrm{CR} 1^{\mathrm{HET}}$, and $\mathrm{CX}_{3} \mathrm{CR} 1^{\mathrm{KO}}$ mice were subjected to RSD. Anxiety-like behavior was determined $14 \mathrm{~h}$ after the final cycle of RSD. In experiments using $\mathrm{WT}$ and $\mathrm{CCR} 2{ }^{\mathrm{KO}}$ mice, RSD-induced increase in time to enter the open field was dependent on CCR2 expression (RSD-CCR2 interaction: $\left.F_{(1,35)}=13.53, p<0.0009\right)$. For instance, RSD increased time to enter the open field in WT mice $(p<0.006)$, but not in CCR2 ${ }^{\mathrm{KO}}$ mice (Fig. $8 A$ ). Similar results were found in using $\mathrm{CX}_{3} \mathrm{CR} 1^{\mathrm{HET}}$ and $\mathrm{CX}_{3} \mathrm{CR} 1^{\mathrm{KO}}$ mice: time to enter the open field was increased after RSD in $\mathrm{CX}_{3} \mathrm{CR} 1^{\mathrm{HET}}(p<0.03)$, but not in $\mathrm{CX}_{3} \mathrm{CR} 1^{\mathrm{KO}}$ mice. Figure $8 B$ shows that time spent in the open field was reduced after RSD in WT $(p<0.06)$ and $\mathrm{CX}_{3} \mathrm{CR} 1^{\mathrm{HET}}$ mice $(p<0.02)$, but was unaffected by RSD in either CCR $2^{\mathrm{KO}}$ or $\mathrm{CX}_{3} \mathrm{CR} 1^{\mathrm{KO}}$ mice (Fig. $8 D$ ).

Following completion of behavioral testing, brain $\mathrm{CD} 11 \mathrm{~b}^{+}$cells were isolated and the percentage of brain macrophages was determined. Representative dot plots of CD11b/CD45 labeling for genotype groups are shown (Fig. $8 C$ ). There was a significant interaction (stress-genotype) in both experimental groups (RSD-CCR2 interaction: $F_{(1,35)}=12.55, p<0.001$; RSD-CX $\mathrm{CR}_{3}$ interaction: $F_{(1,33)}=6.51$, $p<0.02)$. For example, Figure $8 D$ shows that RSD significantly increased the number of macrophages (CD $11 b^{+} / \mathrm{CD} 45^{\mathrm{hi}}$ ) associated with the brain of WT and

Table 2. RSD increased IL-1 $\beta$ mRNA expression in the CTX-R, BG, HYPO, and HPC independent of genotype

\begin{tabular}{|c|c|c|}
\hline Region: genotype & Controls & RSD \\
\hline \multicolumn{3}{|l|}{ CTX-R: } \\
\hline WT & $1.05 \pm 0.16$ & $2.76 \pm 0.18^{*}$ \\
\hline $\mathrm{CCR} 2^{\mathrm{K} 0}$ & $1.18 \pm 0.19$ & $1.68 \pm 0.29$ \\
\hline $\mathrm{CX}_{3} \mathrm{CR} 1^{\mathrm{HET}}$ & $1.47 \pm 0.21$ & $2.18 \pm 0.38^{\#}$ \\
\hline $\mathrm{CX}_{3} \mathrm{CR} 1^{\mathrm{K} 0}$ & $1.63 \pm 0.27$ & $2.00 \pm 0.24$ \\
\hline \multicolumn{3}{|l|}{ BG: } \\
\hline WT & $1.01 \pm 0.09$ & $2.98 \pm 0.84^{*}$ \\
\hline $\mathrm{CCR} 2^{\mathrm{K} 0}$ & $1.25 \pm 0.24$ & $2.52 \pm 0.42^{*}$ \\
\hline$C X_{3} C R 1^{\mathrm{HET}}$ & $1.08 \pm 0.06$ & $3.01 \pm 0.52^{*}$ \\
\hline $\mathrm{CX}_{3} \mathrm{CR} 1^{\mathrm{KO}}$ & $1.22 \pm 0.04$ & $2.82 \pm 0.56^{*}$ \\
\hline \multicolumn{3}{|l|}{ HYPO: } \\
\hline WT & $1.04 \pm 0.16$ & $2.74 \pm 0.47^{*}$ \\
\hline $\mathrm{CCR}^{\mathrm{K} 0}$ & $1.40 \pm 0.12$ & $2.44 \pm 0.38^{\#}$ \\
\hline $\mathrm{CX}_{3} \mathrm{CR} 1^{\mathrm{HET}}$ & $1.16 \pm 0.21$ & $2.16 \pm 0.32^{*}$ \\
\hline $\mathrm{CX}_{3} \mathrm{CR} 1^{\mathrm{K} 0}$ & $1.25 \pm 0.21$ & $2.69 \pm 0.54^{*}$ \\
\hline \multicolumn{3}{|l|}{ HPC: } \\
\hline WT & $1.01 \pm 0.07$ & $3.46 \pm 0.97^{*}$ \\
\hline $\mathrm{CCR}^{\mathrm{K} 0}$ & $1.15 \pm 0.02$ & $2.39 \pm 0.33^{*}$ \\
\hline $\mathrm{CX}_{3} \mathrm{CR}^{\mathrm{HET}}$ & $1.65 \pm 0.41$ & $3.20 \pm 0.66^{*}$ \\
\hline $\left.\mathrm{CX}_{3} \mathrm{CR}\right)^{\mathrm{KO}}$ & $1.27 \pm 0.18$ & $3.00 \pm 0.54^{*}$ \\
\hline
\end{tabular}

Male WT, $\mathrm{CCR}_{2}{ }^{\mathrm{K} 0}, \mathrm{CX}_{3} \mathrm{CR} 1{ }^{\mathrm{HET}}$, and $\mathrm{CX}_{3} \mathrm{CR}^{\mathrm{K} 0}{ }^{\mathrm{C}} \mathrm{C} 7 \mathrm{BL} / 6$ mice were subjected to six cycles of social defeat (RSD) or left undisturbed as controls. Brains were removed, dissected, and frozen in liquid nitrogen $14 \mathrm{~h}$ after the final cycle of RSD. IL- $1 \beta$ mRNA levels were determined in the CTX-R, HYPO, BG, and HPC ( $n=4-6,4$ independent experiments). Values represent average fold change compared to WT control. Means with asterisk $\left(^{*}\right)$ are significantly different from controls $(p<0.05)$ and means with number sign (\#) are different from controls $(p<0.10)$.
$\mathrm{CX}_{3} \mathrm{CR} 1^{\mathrm{HET}}$ mice $\left(p<0.02\right.$, for each), but not in either CCR2 ${ }^{\mathrm{KO}}$ or $\mathrm{CX}_{3} \mathrm{CR} 1^{\mathrm{KO}}$ mice. Together, these data indicate that deficiency in either CCR2 or $\mathrm{CX}_{3} \mathrm{CR} 1$ blocked RSD-induced macrophage recruitment to the brain and prevented the development of anxiety-like behavior.

\section{Expression of CCR 2 and $C X_{3} C R 1$ was required for $B M$-derived} macrophage infiltration into the brain parenchyma

To further evaluate the role of CCL2-CCR2 and CX $_{3}$ CL1$\mathrm{CX}_{3} \mathrm{CR} 1$ signaling in myeloid cell trafficking to the brain, BMchimeric mice were generated using donor $\mathrm{BM}$ from transgenic $\mathrm{CCR} 2^{\mathrm{HET}(+/ \mathrm{RFP})}$ or $\mathrm{CCR} 2^{\mathrm{KO}(\mathrm{RFP} / \mathrm{RFP})}$ and $\mathrm{CX}_{3} \mathrm{CR} 1^{\mathrm{HET}(+/ \mathrm{GFP})}$ or $\mathrm{CX}_{3} \mathrm{CR} 1^{\mathrm{KO}(\mathrm{GFP} / \mathrm{GFP})}$ mice. In these experiments, all recipient mice were $\mathrm{WT}$ and received either CCR $2^{\mathrm{HET}(+/ \mathrm{RFP})}, \mathrm{CCR} 2^{\mathrm{KO}(\mathrm{RFP} /}$ $\mathrm{RFP}), \mathrm{CX}_{3} \mathrm{CR} 1^{\mathrm{HET}(+/ \mathrm{GFP})}$, or $\mathrm{CX}_{3} \mathrm{CR} 1^{\mathrm{KO}(\mathrm{GFP} / \mathrm{GFP})} \mathrm{BM}$-derived donor cells. BM-chimera mice were then subjected to six cycles of social defeat (RSD) and brains were collected $14 \mathrm{~h}$ after the final cycle to determine the neuroanatomical distribution of peripheral myeloid cells $\left(\mathrm{RFP}^{+}\right.$or $\left.\mathrm{GFP}^{+}\right)$. In the CCR2 donor studies, $\mathrm{RFP}^{+}$peripheral macrophages were detected in the PVS, but no $\mathrm{RFP}^{+}$macrophages could be visualized in the brain parenchyma (Fig. 9A). Because infiltrating monocytes can downregulate CCR2 expression after BBB extravasation (Mahad et al., 2006), parenchymal macrophages were distinguished from microglia by Iba-1 morphology. Quantification of perivascular and ramified peripheral macrophages showed that CCR2 ${ }^{\mathrm{HET}}$ recipient mice had more total peripheral macro- 
phages in the PFC $\left(F_{(1,15)}=7.25, p<0.02\right.$; Fig. 9B), $\operatorname{AMYG}\left(F_{(1,15)}=7.83, p<0.02\right.$; Fig. $9 C)$, and $\operatorname{HPC}\left(F_{(1,15)}=6.08, p<0.03\right.$; Fig. 9D). CCR2 ${ }^{\mathrm{HET}}$ recipient mice also had an increased presence of parenchymal macrophages in the PFC (main effect of genotype; $F_{(1,15)}=5.34, p<0.04$; Fig. $9 B$ ) and AMYG (main effect of genotype; $F_{(1,15)}=$ $8.92, p<0.01)$ compared with CCR2 ${ }^{\mathrm{KO}}$ recipient mice, but RSD did not significantly affect macrophage trafficking in these regions. In contrast, RSD promoted infiltration of peripheral macrophages into the PVS and parenchyma in the HPC ofCCR $2{ }^{\mathrm{HET}}$ recipient mice compared with CCR $2{ }^{\mathrm{KO}}$ recipient mice $(p<$ 0.06 , for both).

In the $\mathrm{CX}_{3} \mathrm{CR} 1$ donor studies, $\mathrm{GFP}^{+}$ peripheral macrophages were identified in the PVS and brain parenchyma (Fig. 9E). Similar to the results using WT GFP ${ }^{+}$ BM donor cells (Figs. 5-7), RSD markedly enhanced the total number of peripheral macrophages in the PFC (main effect of RSD, $F_{(1,26)}=5.80, p<0.02$ ), AMYG (main effect of RSD, $\left.F_{(1,24)}=7.75, p<0.01\right)$, and HPC (main effect of RSD, $F_{(1,24)}=3.07, p=$ 0.09 ) of $\mathrm{CX}_{3} \mathrm{CR} 1^{\mathrm{HET}}$ recipient mice (Fig. $9 E-G)$. In addition, RSD caused infiltration of peripheral macrophages $\left(\mathrm{GFP}^{+}\right)$ into the PFC (RSD-genotype interaction, $\left.F_{(1,26)}=9.34, p<0.006\right)$, AMYG (RSDgenotype interaction, $F_{(1,24)}=6.89, p<$ 0.02 ), and HPC (RSD-genotype interaction, $\left.F_{(1,24)}=3.30, p=0.07\right)$ of $\mathrm{CX}_{3} \mathrm{CR} 1^{\mathrm{HET}}$ recipient mice, but not $\mathrm{CX}_{3} \mathrm{CR} 1^{\mathrm{KO}}$ recipient mice. Again it is important to emphasize that infiltration of $\mathrm{CCR} 2^{\mathrm{RFP}}$ and $\mathrm{CX}_{3} \mathrm{CR} 1^{\mathrm{GFP}}$ myeloid cells into the brain parenchyma was limited in control mice. Furthermore, parenchymal macrophages had high expression of Iba-1 and displayed a distinct ramified phenotype compared with microglia. Together, these data demonstrate that expression of CCR2 and $\mathrm{CX}_{3} \mathrm{CR} 1$ on myeloid cells was required to infiltrate the brain parenchyma following RSD.

\section{Discussion}

Mounting evidence indicates that stress promotes inflammation and immune dysfunction (Glaser and Kiecolt-Glaser, 2005) that contributes to development of mood disorders (Haroon et al., 2012). In the current study, social defeat promoted recruitment of peripheral macrophages to the brain that was integral to the development of anxiety-like behavior. Of note, RSD caused regionspecific infiltration of peripheral macrophages into the brain parenchyma of $\mathrm{GFP}^{+}$BM-chimeric mice. Moreover, RSD-induced macrophage recruitment to the brain and development of anxiety required expression of both $\mathrm{CCR} 2$ and $\mathrm{CX}_{3} \mathrm{CR} 1$. These findings provide insight into how stress-induced myeloid cell recruitment alters the neuroimmune profile and promotes anxiety-like behavior.

Our previous reports indicate that RSD primes peripheral myeloid cells that readily traffic to peripheral tissues (Engler et al., 2004) and the brain (Wohleb et al., 2011). Here we extend these findings to show that social defeat increased circulating monocytes $\left(\mathrm{CD}_{11} \mathrm{~b}^{+} / \mathrm{SSC}^{\mathrm{lo}} / \mathrm{Ly} \mathrm{C}^{\mathrm{hi}}\right)$ and brain macrophages $\left(\mathrm{CD} 11 \mathrm{~b}^{+} /\right.$ $\mathrm{CD} 45^{\text {hi }}$ ) in a cycle-dependent manner that corresponded with development of anxiety. In WT and LysM-GFP ${ }^{+}$mice, stress-induced
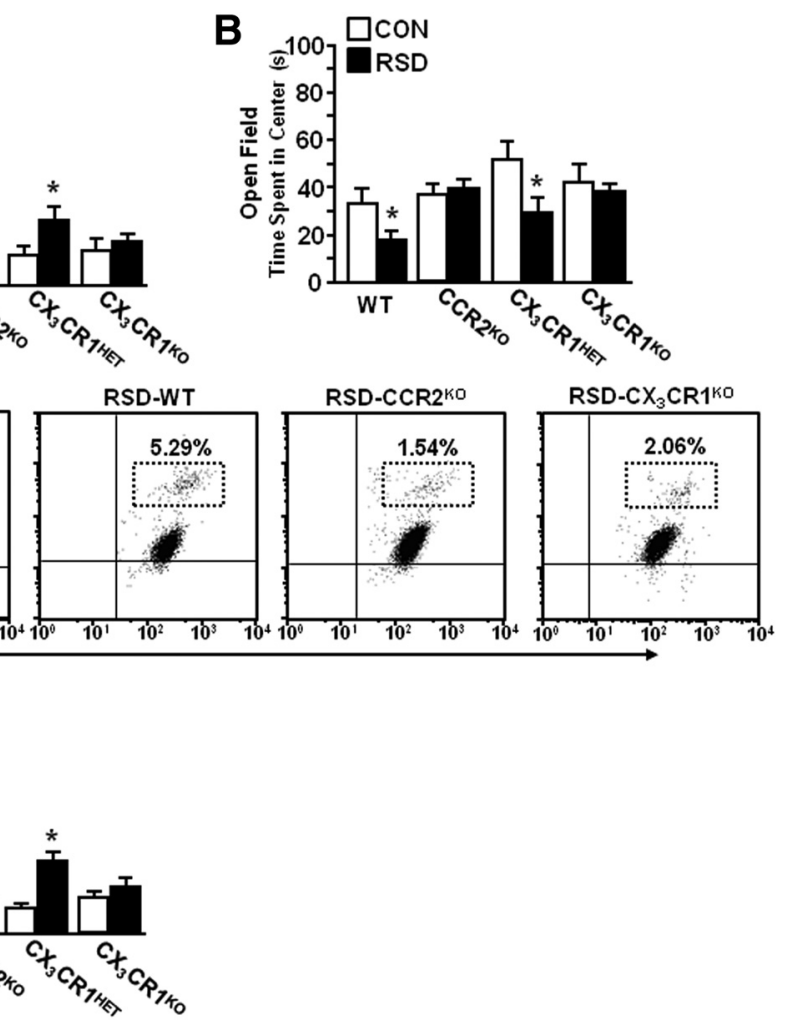

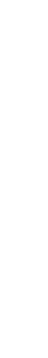

Figure 8. RSD-induced macrophage recruitment to the brain and anxiety-like behavior required expression of CCR2 and

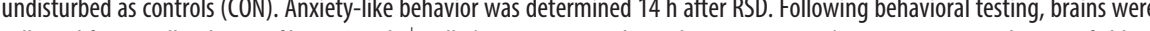
, Representative flow bivariate dot plots of CD11b/CD45 labeling of Percoll-isolated microglia/ macrophages. $\boldsymbol{D}$, The percentage of brain macrophages. Bars represent the mean \pm SEM. Means with asterisk $\left(^{*}\right)$ are significantly different from genotype CON $(p<0.05)$.

anxiety-like behavior was established after six cycles of RSD and corresponded with increased proportion of circulating monocytes $\left(\mathrm{CD}_{11 \mathrm{~b}}{ }^{+} / \mathrm{SSC}^{\mathrm{lo}} / \mathrm{Ly}_{6 \mathrm{C}} \mathrm{C}^{\mathrm{hi}}\right)$, brain macrophages $\left(\mathrm{GFP}^{+} / \mathrm{CD} 11 \mathrm{~b}^{+} /\right.$ $\left.\mathrm{CD} 45^{\mathrm{hi}}\right)$, and perivascular macrophages $\left(\mathrm{GFP}^{+} / \mathrm{Iba}-1^{\mathrm{lo}}\right)$. Furthermore, LysM-GFP ${ }^{+}$and $\mathrm{GFP}^{+} \mathrm{BM}$-chimeric mice confirmed that peripheral monocytes were recruited to the brain and developed into macrophages. Stress-induced release of primed myeloid cells is associated with activation of the sympathetic nervous system and release of norepinephrine in the BM (Spiegel et al., 2007; Hanke et al., 2012). In support of this notion, $\beta$-adrenergic receptor antagonism blocked RSD-induced myeloid cell activation and resulted in reduced macrophage trafficking to the brain (Wohleb et al., 2011; Hanke et al., 2012). Collectively, these studies demonstrate that RSD caused release of primed monocytes into circulation that traffic to the brain.

Several reports indicate that stress-induced neuroinflammation is mediated by activation of resident microglia (Blandino et al., 2006; Frank et al., 2007; Wohleb et al., 2011). In our model (RSD), resident immune cells (i.e., microglia) likely contribute to macrophage recruitment because RSD increased IL- $1 \beta$ and CCL 2 mRNA expression in the CTX-R, HYPO, BG, and HPC. Indeed microglia increase IL- $1 \beta$ and CCL 2 to promote macrophage recruitment into the brain (Ching et al., 2007; D'Mello et al., 2009), but trafficking myeloid cells can propagate these signals as well. In the CTX-R, HYPO, and BG, there was a cycle-dependent reduction in $\mathrm{CX}_{3} \mathrm{CL} 1$. Therefore, stressinduced macrophage recruitment corresponded with neuroinflammatory mediators that facilitate myeloid cell trafficking in the brain (Prinz and Priller, 2010). 
A

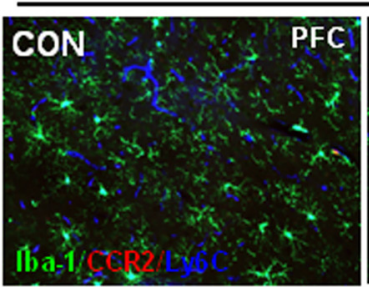

B

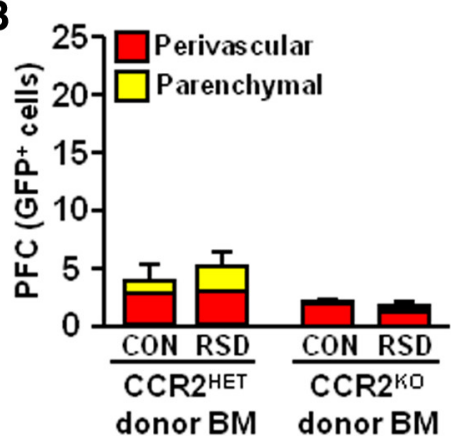

donor BM

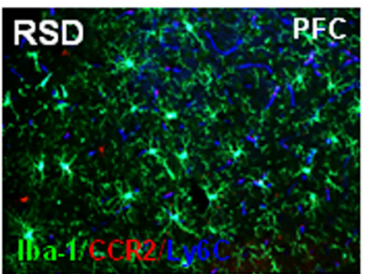

C

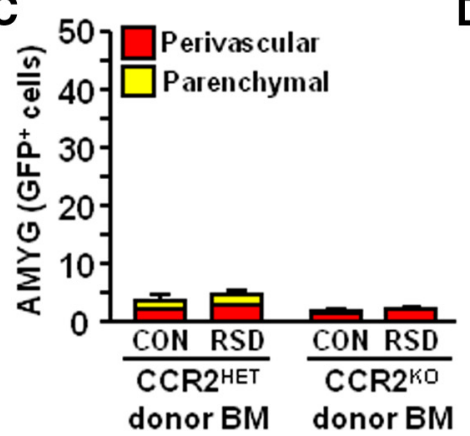

CCR2KO(RFPIRFP) donor BM
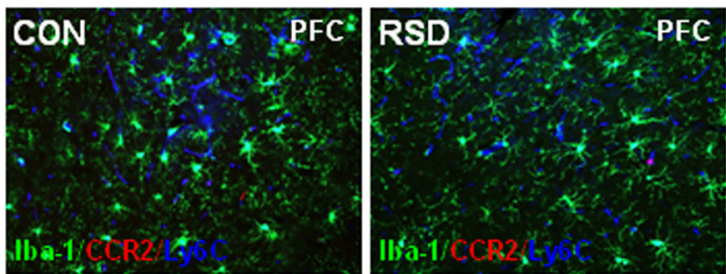

D

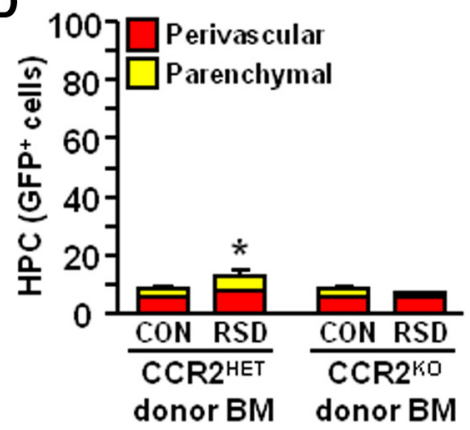

E

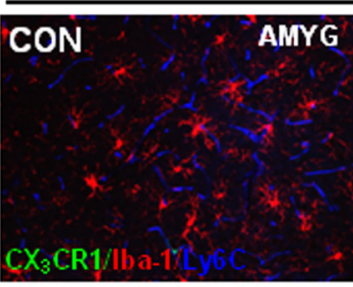

$\mathbf{F}$

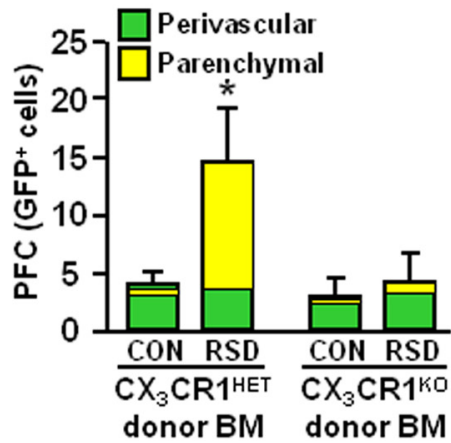

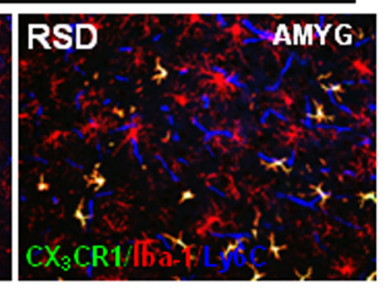

G

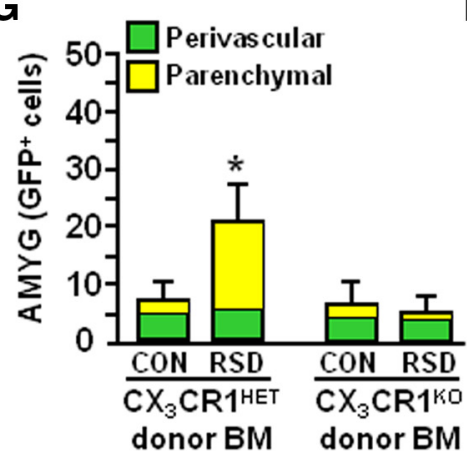

$\mathrm{CX}_{3} \mathrm{CR}^{\text {KO(GFP/GFP) donor } \mathrm{BM}}$

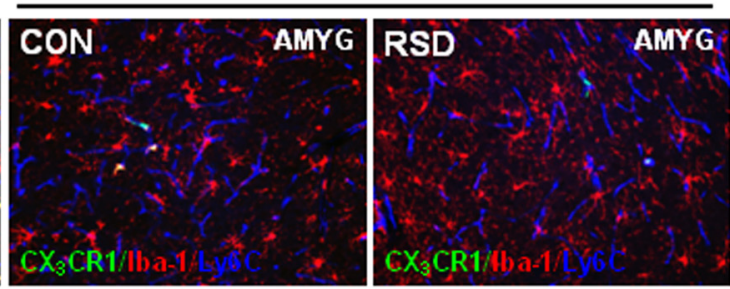

H

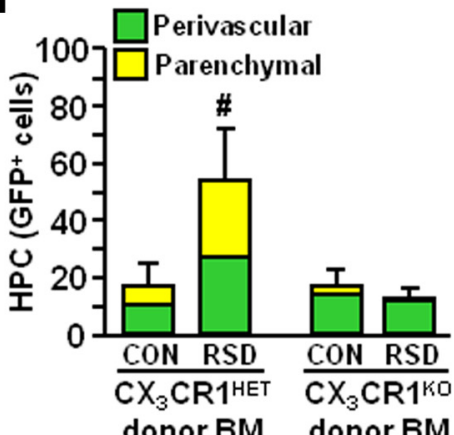

Figure 9. Expression of $C C R 2$ and $C X_{3} C R 1$ on peripheral myeloid cells was required for RSD-induced macrophage infiltration into the brain parenchyma. WT recipient mice received either

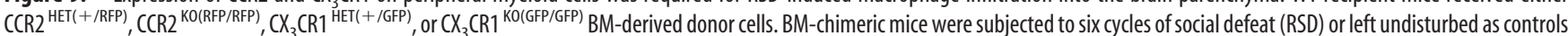
(CON). The neuroanatomical distribution of GFP ${ }^{+}$cells was determined $14 \mathrm{~h}$ after the final cycle of RSD ( $n=3-6,2$ independent experiments). $A$, Representative merged images of Iba- 1 (green)/CCR2 (red)/Ly6C (blue) immunofluorescence in the PFC of CON or RSD mice that received CCR2 ${ }^{\mathrm{HET}}$ and CCR2 ${ }^{\mathrm{KO}}$ donor BM. $\boldsymbol{B}-\boldsymbol{D}$, Quantification of the total number of perivascular and parenchymal cells in the PFC $(\boldsymbol{B})$, AMYG $(\boldsymbol{C})$, and HPC (D). $\boldsymbol{E}$, Representative merged images of $\mathrm{XX}_{3} \mathrm{CR} 1$ (green)/lba-1 (red)/Ly6C (blue) immunofluorescence in the AMYG of CON or RSD mice that received $C X_{3} C R 1^{\mathrm{HET}}$ or $C X_{3} C R 1^{\mathrm{K} 0}$ donor BM. $\boldsymbol{F}-\boldsymbol{H}$, Quantification of the total number of perivascular and parenchymal GFP ${ }^{+}$cells in the PFC $(\boldsymbol{F})$, $\mathrm{AMYG}(\boldsymbol{G})$, and $\mathrm{HPC}(\boldsymbol{H})$. Bars represent the mean \pm SEM. Means with asterisk $\left(^{*}\right)$ are significantly different from CON $(p<0.05)$ and means with number sign (\#) tend to be different from CON $(p=0.06)$.

Coinciding with increased neuroinflammation after RSD, we show novel data that RSD caused significant recruitment of peripheral macrophages to brain PVS and parenchyma. Indeed, RSD increased perivascular macrophages associated with the brain of LysM-GFP ${ }^{+}$and $\mathrm{GFP}^{+} / \mathrm{RFP}^{+} \mathrm{BM}$-chimera mice. Consistent with other studies, perivascular macrophages had rod/ circular morphology, low expression of Iba-1, and were localized in the vasculature (Vallières and Sawchenko, 2003). In addition, RSD caused robust infiltration of ramified macrophages (Iba$1^{+}$) in the brain parenchyma of $\mathrm{GFP}^{+} / \mathrm{RFP}^{+} \mathrm{BM}$-chimera mice. Parenchymal macrophages had high expression of Iba-1 similar to resident microglia, but had a distinct ramified morphology (Varvel et al., 2012). Other GFP ${ }^{+}$BM-chimera studies show that neurological disease caused comparable myeloid cell trafficking into the brain parenchyma. In these experiments BM-chimera mice were generated with irradiation, which alone can facilitate myeloid cell entry into the brain (Mildner et al., 2007; Ajami et al., 2011). Our findings show that busulfan BM-chimera mice do not have generalized BBB permeability and, similar to other studies, busulfan did not promote nonspecific myeloid cell trafficking into the brain (Lampron et al., 2012; Kierdorf et al., 2013). Nonetheless, busulfan is an alkylating agent that may alter neuroim- 
mune properties, but in this study there was no indication of aberrant effects. Together, robust macrophage recruitment in the brain was evident following psychosocial stress that was unrelated to any neurological disease, infection, or trauma.

A novel finding in this study was that RSD-induced recruitment of $\mathrm{GFP}^{+}$macrophages occurred preferentially in stressresponsive brain regions. For example, RSD markedly increased parenchymal macrophages (ramified $\mathrm{GFP}^{+} / \mathrm{Iba}^{-}{ }^{+}$) in the PFC, AMYG, LS, BNST, PVN, AMYG, and HPC of WT GFP ${ }^{+} \mathrm{BM}-$ chimeric mice. Moreover, there was limited RSD-induced trafficking of $\mathrm{GFP}^{+}$macrophages into the M1 CTX, somatosensory cortex, and cerebellum. This specific pattern of macrophage infiltration is relevant because these are key areas associated with fear and anxiety responses (Ressler and Mayberg, 2007; Shin and Liberzon, 2010). In addition, brain regions that had robust macrophage recruitment had increased mRNA expression of IL-1 $\beta$ and CCL2 (Table 1), enhanced neuronal (c-Fos) activation, and pronounced microglia ( $\mathrm{Iba}-1^{+}$) activation following RSD (Wohleb et al., 2011). These data indicate that RSD promoted brain region-specific activation that may facilitate macrophage recruitment and integration into the parenchyma.

Another key finding is that disruption of macrophage recruitment to the brain in CCR $2^{\mathrm{KO}}$ and $\mathrm{CX}_{3} \mathrm{CR} 1^{\mathrm{KO}}$ mice prevented RSD-induced anxiety-like behavior. These studies demonstrated a direct link between RSD-induced macrophage accumulation in the brain and anxiety-like behavior. Reduced myeloid cell trafficking in these mice may be related to impaired monocyte development and function in CCR $2{ }^{\mathrm{KO}}$ (Serbina and Pamer, 2006) and $\mathrm{CX}_{3} \mathrm{CR} 1^{\mathrm{KO}}$ mice (Auffray et al., 2007). The essential role of CCR2 in monocyte trafficking was substantiated in studies using CCR $2{ }^{\text {RFP }}$ BM-chimera mice. In these studies CCR2 ${ }^{\mathrm{HET}}$ recipient mice had significantly more brain macrophages than CCR2 ${ }^{\mathrm{KO}}$ recipients overall. However, CCR ${ }^{\mathrm{KO}}$ and CCR $2^{\mathrm{HET}}$ recipient mice did not show robust macrophage recruitment after RSD. Moreover, $\mathrm{CX}_{3} \mathrm{CR} 1{ }^{\mathrm{GFP}} \mathrm{BM}$-chimera mice revealed that $\mathrm{CX}_{3} \mathrm{CR} 1$ expression was integral for RSD-induced macrophage recruitment in the brain PVS and parenchyma. Together, CCR2 is essential in development of monocytes and targeting of these cells to the brain (from the blood) while $\mathrm{CX}_{3} \mathrm{CR} 1$ is critical for their integration in the brain PVS and parenchyma. These findings are consistent with other studies that show CCR2 and $\mathrm{CX}_{3} \mathrm{CR} 1$ mediate myeloid cell recruitment in neurological disease and injury (Mahad et al., 2006; Mildner et al., 2009; Saederup et al., 2010; Ajami et al., 2011; Donnelly et al., 2011; Yao and Tsirka, 2012). While similar mechanisms enable myeloid cell trafficking in the brain, RSD-induced macrophage recruitment occurs without pathology and likely use unique chemokine receptor interactions to enter the brain. These results indicate that RSD-induced macrophage recruitment into the brain is a dynamic process that requires expression of both CCR2 and $\mathrm{CX}_{3} \mathrm{CR} 1$. Furthermore, impairments in either CCR2 or $\mathrm{CX}_{3} \mathrm{CR} 1$ prevents monocyte trafficking and blocks development of stress-induced anxiety.

Related to the points above, RSD increased mRNA expression of IL- $1 \beta$ in the HYPO, BG, and HPC, but did not change IL- $1 \beta$ in the CTX-R of CCR $2{ }^{\mathrm{KO}}$ and $\mathrm{CX}_{3} \mathrm{CR} 1^{\mathrm{KO}}$ mice (Table 2). Reduced IL- $1 \beta$ expression in the CTX-R of CCR $2^{\mathrm{KO}}$ and $\mathrm{CX}_{3} \mathrm{CR} 1^{\mathrm{KO}}$ is likely related to impaired macrophage recruitment and suggests it is susceptible to stress-induced inflammatory signaling (Munhoz et al., 2006). Moreover, these data indicate that increased IL-1 $\beta$ levels alone were insufficient to cause anxiety-like behavior and appear to contradict other reports that indicate IL- $1 \beta$ modulates behavioral responses to stressors (Goshen and Yirmiya, 2009). We postulate, however, that IL- $1 \beta$ signaling is integral in the recruitment of macrophages to the brain after RSD. In support of this interpretation, mice lacking IL-1 receptor (IL-1R1 ${ }^{\mathrm{KO}}$ ) do not develop primed myeloid cells (Engler et al., 2008) or anxiety-like behavior after RSD (Wohleb et al., 2011). Therefore, in this model of social stress, IL- $1 \beta$ plays an indirect, but critical, role in the development of anxiety through the recruitment of primed macrophages to the brain.

The current findings along with our previous work indicate that RSD causes release of primed myeloid cells into circulation (Engler et al., 2004) and recruitment of these cells is likely initiated by activation of resident immune cells in the brain (Wohleb et al., 2011). With the exception of CCR2 ${ }^{\mathrm{KO}}$ and $\mathrm{CX}_{3} \mathrm{CR} 1^{\mathrm{KO}}$ mice, RSD caused a significant increase of macrophages in the brain that coincided with development of anxiety. For example, six cycles of social defeat increased the presence of brain macrophages and caused anxiety in WT and LysM-GFP ${ }^{+}$mice. In some circumstances, RSD promoted macrophage infiltration into the brain parenchyma, but also caused macrophage accumulation in the PVS. Redistribution of primed macrophages in the brain after RSD is important because these cells activate resident microglia and generate secondary mediators (i.e., prostaglandins) and cytokines that influence neurobehavioral responses (Serrats et al., 2010; Tanaka et al., 2012). These data have translational relevance because psychosocial stress in humans also alters the distribution and inflammatory status of myeloid cells (Miller et al., 2008; Dhabhar, 2009; Cole et al., 2010). Thus, monocyte redistribution in the brain may be a critical determinant of behavioral disorders associated with psychosocial stress (for review, see Beumer et al., 2012).

In summary, these results reveal a novel mechanism by which social stress promotes anxiety-like behavior. Stress caused recruitment of BM-derived monocytes to the brain that develop into perivascular macrophages and can infiltrate into specific stress-responsive brain regions. Moreover, stress-induced macrophage recruitment to the brain was integral for the development of anxiety. Together, our results demonstrate a key role for primed macrophages recruited to the brain during psychosocial stress and provide an innovative cellular perspective on the pathophysiology of stress-induced anxiety.

\section{References}

Ajami B, Bennett JL, Krieger C, McNagny KM, Rossi FM (2011) Infiltrating monocytes trigger EAE progression, but do not contribute to the resident microglia pool. Nat Neurosci 14:1142-1149. CrossRef Medline

Auffray C, Fogg D, Garfa M, Elain G, Join-Lambert O, Kayal S, Sarnacki S, Cumano A, Lauvau G, Geissmann F (2007) Monitoring of blood vessels and tissues by a population of monocytes with patrolling behavior. Science 317:666-670. CrossRef Medline

Bailey MT, Kinsey SG, Padgett DA, Sheridan JF, Leblebicioglu B (2009) Social stress enhances IL-1beta and TNF-alpha production by Porphyromonas gingivalis lipopolysaccharide-stimulated CD11b + cells. Physiol Behav 98:351-358. CrossRef Medline

Beumer W, Gibney SM, Drexhage RC, Pont-Lezica L, Doorduin J, Klein HC, Steiner J, Connor TJ, Harkin A, Versnel MA, Drexhage HA (2012) The immune theory of psychiatric diseases: a key role for activated microglia and circulating monocytes. J Leukoc Biol 92:959-975. CrossRef Medline

Blandino P Jr, Barnum CJ, Deak T (2006) The involvement of norepinephrine and microglia in hypothalamic and splenic IL-1beta responses to stress. J Neuroimmunol 173:87-95. CrossRef Medline

Brydon L, Edwards S, Jia H, Mohamed-Ali V, Zachary I, Martin JF, Steptoe A (2005) Psychological stress activates interleukin-1beta gene expression in human mononuclear cells. Brain Behav Immun 19:540-546. CrossRef Medline

Ching S, Zhang H, Belevych N, He L, Lai W, Pu XA, Jaeger LB, Chen Q, Quan N (2007) Endothelial-specific knockdown of interleukin-1 (IL-1) type 1 receptor differentially alters CNS responses to IL-1 depending on its route of administration. J Neurosci 27:10476-10486. CrossRef Medline 
Christoffel DJ, Golden SA, Dumitriu D, Robison AJ, Janssen WG, Ahn HF, Krishnan V, Reyes CM, Han MH, Ables JL, Eisch AJ, Dietz DM, Ferguson D, Neve RL, Greengard P, Kim Y, Morrison JH, Russo SJ (2011) Ikap$\mathrm{paB}$ kinase regulates social defeat stress-induced synaptic and behavioral plasticity. J Neurosci 31:314-321. CrossRef Medline

Cole SW, Arevalo JM, Takahashi R, Sloan EK, Lutgendorf SK, Sood AK, Sheridan JF, Seeman TE (2010) Computational identification of genesocial environment interaction at the human IL6 locus. Proc Natl Acad Sci U S A 107:5681-5686. CrossRef Medline

Cross M, Mangelsdorf I, Wedel A, Renkawitz R (1988) Mouse lysozyme M gene: isolation, characterization, and expression studies. Proc Natl Acad Sci U S A 85:6232-6236. CrossRef Medline

Dhabhar FS (2009) Enhancing versus suppressive effects of stress on immune function: implications for immunoprotection and immunopathology. Neuroimmunomodulation 16:300-317. CrossRef Medline

Dhabhar FS, Malarkey WB, Neri E, McEwen BS (2012) Stress-induced redistribution of immune cells-from barracks to boulevards to battlefields: a tale of three hormones-Curt Richter Award winner. Psychoneuroendocrinology 37:1345-1368. CrossRef Medline

D’Mello C, Le T, Swain MG (2009) Cerebral microglia recruit monocytes into the brain in response to tumor necrosis factoralpha signaling during peripheral organ inflammation. J Neurosci 29:2089-2102. CrossRef Medline

Donnelly DJ, Longbrake EE, Shawler TM, Kigerl KA, Lai W, Tovar CA, Ransohoff RM, Popovich PG (2011) Deficient CX3CR1 signaling promotes recovery after mouse spinal cord injury by limiting the recruitment and activation of Ly6Clo/iNOS ${ }^{+}$macrophages. J Neurosci 31:9910-9922. CrossRef Medline

Engler H, Bailey MT, Engler A, Sheridan JF (2004) Effects of repeated social stress on leukocyte distribution in bone marrow, peripheral blood and spleen. J Neuroimmunol 148:106-115. CrossRef Medline

Engler H, Bailey MT, Engler A, Stiner-Jones LM, Quan N, Sheridan JF (2008) Interleukin-1 receptor type 1-deficient mice fail to develop social stressassociated glucocorticoid resistance in the spleen. Psychoneuroendocrinology 33:108-117. CrossRef Medline

Faust N, Varas F, Kelly LM, Heck S, Graf T (2000) Insertion of enhanced green fluorescent protein into the lysozyme gene creates mice with green fluorescent granulocytes and macrophages. Blood 96:719-726. Medline

Frank MG, Baratta MV, Sprunger DB, Watkins LR, Maier SF (2007) Microglia serve as a neuroimmune substrate for stress-induced potentiation of CNS pro-inflammatory cytokine responses. Brain Behav Immun 21:47-59. CrossRef Medline

Geissmann F, Jung S, Littman DR (2003) Blood monocytes consist of two principal subsets with distinct migratory properties. Immunity 19:71-82. CrossRef Medline

Glaser R, Kiecolt-Glaser JK (2005) Stress-induced immune dysfunction: implications for health. Nat Rev Immunol 5:243-251. CrossRef Medline

Goshen I, Yirmiya R (2009) Interleukin-1 (IL-1): a central regulator of stress responses. Front Neuroendocrinol 30:30-45. CrossRef Medline

Hanke ML, Powell ND, Stiner LM, Bailey MT, Sheridan JF (2012) Beta adrenergic blockade decreases the immunomodulatory effects of social disruption stress. Brain Behav Immun 26:1150-1159. CrossRef Medline

Hanna RN, Carlin LM, Hubbeling HG, Nackiewicz D, Green AM, Punt JA, Geissmann F, Hedrick CC (2011) The transcription factor NR4A1 (Nur77) controls bone marrow differentiation and the survival of Ly6Cmonocytes. Nat Immunol 12:778-785. CrossRef Medline

Haroon E, Raison CL, Miller AH (2012) Psychoneuroimmunology meets neuropsychopharmacology: translational implications of the impact of inflammation on behavior. Neuropsychopharmacology 37:137-162. CrossRef Medline

Kierdorf K, Katzmarski N, Haas CA, Prinz M (2013) Bone marrow cell recruitment to the brain in the absence of irradiation or parabiosis bias. PLoS One 8:e58544. CrossRef Medline

Kim JV, Kang SS, Dustin ML, McGavern DB (2009) Myelomonocytic cell recruitment causes fatal CNS vascular injury during acute viral meningitis. Nature 457:191-195. CrossRef Medline

Kinsey SG, Bailey MT, Sheridan JF, Padgett DA, Avitsur R (2007) Repeated social defeat causes increased anxiety-like behavior and alters splenocyte function in C57BL/6 and CD-1 mice. Brain Behav Immun 21:458-466. CrossRef Medline

Krishnan V, Han MH, Graham DL, Berton O, Renthal W, Russo SJ, Laplant Q, Graham A, Lutter M, Lagace DC, Ghose S, Reister R, Tannous P, Green
TA, Neve RL, Chakravarty S, Kumar A, Eisch AJ, Self DW, Lee FS, et al. (2007) Molecular adaptations underlying susceptibility and resistance to social defeat in brain reward regions. Cell 131:391-404. CrossRef Medline Lampron A, Lessard M, Rivest S (2012) Effects of myeloablation, peripheral chimerism, and whole-body irradiation on the entry of bone marrowderived cells into the brain. Cell Transplant 21:1149-1159. CrossRef Medline

Mahad D, Callahan MK, Williams KA, Ubogu EE, Kivisäkk P, Tucky B, Kidd G, Kingsbury GA, Chang A, Fox RJ, Mack M, Sniderman MB, Ravid R, Staugaitis SM, Stins MF, Ransohoff RM (2006) Modulating CCR2 and CCL2 at the blood-brain barrier: relevance for multiple sclerosis pathogenesis. Brain 129:212-223. Medline

Mildner A, Schmidt H, Nitsche M, Merkler D, Hanisch UK, Mack M, Heikenwalder M, Brück W, Priller J, Prinz M (2007) Microglia in the adult brain arise from Ly-6ChiCCR2+ monocytes only under defined host conditions. Nat Neurosci 10:1544-1553. CrossRef Medline

Mildner A, Mack M, Schmidt H, Brück W, Djukic M, Zabel MD, Hille A, Priller J, Prinz M (2009) CCR2+Ly-6Chi monocytes are crucial for the effector phase of autoimmunity in the central nervous system. Brain 132: 2487-2500. CrossRef Medline

Miller GE, Chen E, Sze J, Marin T, Arevalo JM, Doll R, Ma R, Cole SW (2008) A functional genomic fingerprint of chronic stress in humans: blunted glucocorticoid and increased NF-kappaB signaling. Biol Psychiatry 64: 266-272. CrossRef Medline

Munhoz CD, Lepsch LB, Kawamoto EM, Malta MB, Lima Lde S, Avellar MC, Sapolsky RM, Scavone C (2006) Chronic unpredictable stress exacerbates lipopolysaccharide-induced activation of nuclear factor- $\kappa \mathrm{B}$ in the frontal cortex and hippocampus via glucocorticoid secretion. J Neurosci 26:3813-3820. CrossRef Medline

Paxinos G, Franklin K (2008) The mouse brain in stereotaxic coordinates. 3rd edition. New York: Elsevier Academic.

Prinz M, Priller J (2010) Tickets to the brain: role of CCR2 and CX3CR1 in myeloid cell entry in the CNS. J Neuroimmunol 224:80-84. CrossRef Medline

Ressler KJ, Mayberg HS (2007) Targeting abnormal neural circuits in mood and anxiety disorders: from the laboratory to the clinic. Nat Neurosci 10:1116-1124. CrossRef Medline

Saederup N, Cardona AE, Croft K, Mizutani M, Cotleur AC, Tsou CL, Ransohoff RM, Charo IF (2010) Selective chemokine receptor usage by central nervous system myeloid cells in CCR2-red fluorescent protein knock-in mice. PLoS One 5:e13693. CrossRef Medline

Serbina NV, Pamer EG (2006) Monocyte emigration from bone marrow during bacterial infection requires signals mediated by chemokine receptor CCR2. Nat Immunol 7:311-317. CrossRef Medline

Serrats J, Schiltz JC, García-Bueno B, van Rooijen N, Reyes TM, Sawchenko PE (2010) Dual roles for perivascular macrophages in immune-to-brain signaling. Neuron 65:94-106. CrossRef Medline

Shin LM, Liberzon I (2010) The neurocircuitry of fear, stress, and anxiety disorders. Neuropsychopharmacology 35:169-191. CrossRef Medline

Spiegel A, Shivtiel S, Kalinkovich A, Ludin A, Netzer N, Goichberg P, Azaria Y, Resnick I, Hardan I, Ben-Hur H, Nagler A, Rubinstein M, Lapidot T (2007) Catecholaminergic neurotransmitters regulate migration and repopulation of immature human $\mathrm{CD} 34+$ cells through Wnt signaling. Nat Immunol 8:1123-1131. CrossRef Medline

Stark JL, Avitsur R, Padgett DA, Campbell KA, Beck FM, Sheridan JF (2001) Social stress induces glucocorticoid resistance in macrophages. Am J Physiol Regul Integr Comp Physiol 280:R1799-R1805. Medline

Tanaka K, Furuyashiki T, Kitaoka S, Senzai Y, Imoto Y, Segi-Nishida E, Deguchi Y, Breyer RM, Breyer MD, Narumiya S (2012) Prostaglandin E2mediated attenuation of mesocortical dopaminergic pathway is critical for susceptibility to repeated social defeat stress in mice. J Neurosci 32: 4319-4329. CrossRef Medline

Vallières L, Sawchenko PE (2003) Bone marrow-derived cells that populate the adult mouse brain preserve their hematopoietic identity. J Neurosci 23:5197-5207. Medline

Varvel NH, Grathwohl SA, Baumann F, Liebig C, Bosch A, Brawek B, Thal DR, Charo IF, Heppner FL, Aguzzi A, Garaschuk O, Ransohoff RM, Jucker M (2012) Microglial repopulation model reveals a robust homeostatic process for replacing CNS myeloid cells. Proc Natl Acad Sci U S A 109:18150-18155. CrossRef Medline

Wohleb ES, Hanke ML, Corona AW, Powell ND, Stiner LM, Bailey MT, Nelson RJ, Godbout JP, Sheridan JF (2011) $\beta$-Adrenergic receptor an- 
tagonism prevents anxiety-like behavior and microglial reactivity induced by repeated social defeat. J Neurosci 31:6277-6288. CrossRef Medline

Wohleb ES, Fenn AM, Pacenta AM, Powell ND, Sheridan JF, Godbout JP (2012) Peripheral innate immune challenge exaggerated microglia activation, increased the number of inflammatory CNS macrophages, and prolonged social with- drawal in socially defeated mice. Psychoneuroendocrinology 37:1491-1505. CrossRef Medline

Yao Y, Tsirka SE (2012) The CCL2-CCR2 system affects the progression and clearance of intracerebral hemorrhage. Glia 60:908-918. CrossRef Medline 